Saudi Journal of Biomedical Research

Abbreviated Key Title: Saudi J Biomed Res

ISSN 2518-3214 (Print) |ISSN 2518-3222 (Online)

Scholars Middle East Publishers, Dubai, United Arab Emirates

Journal homepage: https://saudijournals.com

\title{
The Effect of Inhaled Anesthetic Halothane on Liver Cells (Experimental Study of Halothane Toxic Effect in BalbC Mice)
}

Aisha Abduljalil Ashammam ${ }^{1 *}$, Amal Masri Iwhida ${ }^{2}$, Abtisam Miftah Dhaw ${ }^{2}$

${ }^{1}$ Department of Anesthesia, Higher Institute of Sciences and Medical Technology/Abu Salim, Tripoli, Libya

${ }^{1}$ Department of Pharmacy, Higher Institute of Sciences and Medical Technology/Abu Salim, Tripoli, Libya

DOI: $10.36348 /$ sjbr.2022.v07i01.001 | Received: 28.11.2021 | Accepted: 03.01.2022 | Published: 10.01 .2022

*Corresponding author: Aisha Ashammam

Department of Anesthesia, Higher Institute of Sciences and Medical Technology/Abu Salim, Tripoli, Libya

\section{Abstract}

Adverse effects of halothane on the liver range from liver dysfunction to hepatitis, and are more frequent following repeated use. Medical personals are in risk of chronic exposure of wasted halothane. However, there are limited literatures about this effect based on time exposure. To identify and analyze the liver cells changes of halothane exposure to liver cells of Balb/C mice. This experimental study used randomized post-test only control group design in 30 male BalbC mice given $0.011 \mathrm{mg} /$ weight halothane 3 hours daily for two weeks (group 1), four weeks (group 2), six weeks (group 3), six weeks followed by 2 weeks of halothane free (group 4), and without exposure (control group). The liver tissues were HE stained and observed for enlarge, karyorrhexis, and karyolitic of the nucleus. Immunohistochemistry was undertaken to count the percentage of cytocrome-P450 stained brown colour and scored based on its intensity. The difference among groups and between each group were statistically significant $(p<0.05)$, except between group 2 and 4 $(\mathrm{p}=0.078)$, and between group 3 and $4(\mathrm{p}=0.522)$. The difference of cytocrome-P450 expression among groups was not statistically significant $(\mathrm{p}=0.266)$. There was statistically significant difference of abnormal liver cell nucleus changes in groups with different time of halothane exposure $(\mathrm{p}=0.000)$ while no statistically significant difference of cytocromeP450 expressions $(\mathrm{p}=0.266)$ was found. The nucleus changes were gradually increased with the time of exposure.

Keywords: Halothane, liver cell nucleus changes, cytocrome-P450.

Copyright (C) 2022 The Author(s): This is an open-access article distributed under the terms of the Creative Commons Attribution 4.0 International License (CC BY-NC 4.0) which permits unrestricted use, distribution, and reproduction in any medium for non-commercial use provided the original author and source are credited.

\section{INTRODUCTION}

Anesthesia is used in surgery to minimize pain, discomfort, and shock for surgical patients. When anesthesia works as expected, the patient feels no pain during a procedure, and often does not remember the proceedings either. Anesthesia increases patient comfort, which can in turn reduce recovery times and it easier for a medical staff to work (Barash, 2009). Inhalational anesthetics are gases that possess anesthetic qualities that are administered by breathing through an anesthesia mask or endotracheal tube (ET) connected to an anesthetic machine. The agents of significant contemporary interest include the volatile anesthetics (halothane, isoflurane, sevoflurane and desflurane) and the gases ethylene, nitrous oxide and xenon (Njoku et al., 1997).

Halothane is an inhalation anesthetic has been used widely for the induction and maintenance of general anesthesia. The usual dosage of halothane are $0.5 \%$ to $1.5 \%$ (Bednarski, 2009). It has a depressant action on the cardiovascular system and reduces blood pressure by decreasing the cardiac output; signs of over dosage are bradycardia and profound hypotension (Klassen \& Doull, 2001). Its effects on gastrointestinal tract are nausea and vomiting. In the respiratory system, it will cause dose-dependent respiratory depression resulting in hypoxia (Miller et al., 2020). In addition, it has adverse effects on the liver range from liver dysfunction to hepatitis and necrosis, and is more frequent following repeated use. Defective proteolytic degradation of the immunogenic trifluoro acetylated protein caused hepatotoxicity (Klassen et al, 2001).

Following this, (Walton, 1978) have found 204 postoperative hepatic dysfunction from 5,000,000 halothane anesthetics cases, 76 classified as unexplained. Ninety five percent of these cases underwent multiple halothane anesthetics, which 55\% were took place within 4 weeks (Steffey et al, 2015). Hepatic function tests changes resulting from inhalation anesthetics are usually not clinically important 
(Wenker, 1999). Halothane hepatitis is probably caused by trifluoro acetyl-containing metabolites binding to protein and subsequently forming anti-trifluoro acetyl antibodies (Pohl et al., 1996). Halothane hepatotoxicity can occur 5-7 days following exposure, although it can be delayed by up to 4 weeks. Each halo alkaline anesthetic causes liver injury is related to the amount they are metabolized by hepatic CYP enzymes: $20 \%$ to $30 \%$ for halothane, $2 \%$ for enflurane, $1 \%$ for sevoflurane, and $0.2 \%$ or less for isoflurane and desflurane (falahian, 2009). Halothane is associated with highest incidence of hepatic injury with up to 1 case per 35,000 patients developed halothane hepatitis. While lower incidence are associated with isoflurane and desflurane (Eger, 2004).

Cytochrome P450 enzymes is a group of about 60 endogenous enzymes that participate in the metabolism of drug and the synthesis of lipid and steroid hormone. Most of the CYP450 enzymes that are active in drug metabolism are in the liver and the small intestine. CYP450 subtype 2E1 and 2A6 play important role in halothane metabolism. Cytochrome P450 2E1 (CYP2E1) is a major catalyst in the formation of trifluoro acetylated proteins, which have been implicated as target antigens in the mechanism of halothane hepatitis.
Medical personnel within operating theatre are at risk of exposed to wasted halothene during surgery. The total dosage of wasted halotane exposure depend on cumulative duration of the anesthetic time each working days, every weeks, every months or even every years. Therefore, such medical personnel have a risk of tissue damages; e.g. liver, kidney, cardiovascular system, pulmonary system, renal system, and skeletal muscle system. We choose halothane in this research since it is still widely used especially in low income countries (e.g Libya and Egypt) as agent anesthetic of choice in pediatric operation and delivery. High incidence of halothane-associated hepatitis is another reason we choose this agent to be studied in this research.

The scope of the study includes pathobiology and anesthesiology. The study was conducted in Animal Laboratory at Gajah Mada University and the tissue examination was done at department of pathology Gajah Mada University in Yogyakarta. Study design is experimental study, namely post test only control group design. The samples were randomly divided into 4 intervention groups and 1 group for control as shown in Figure 1.

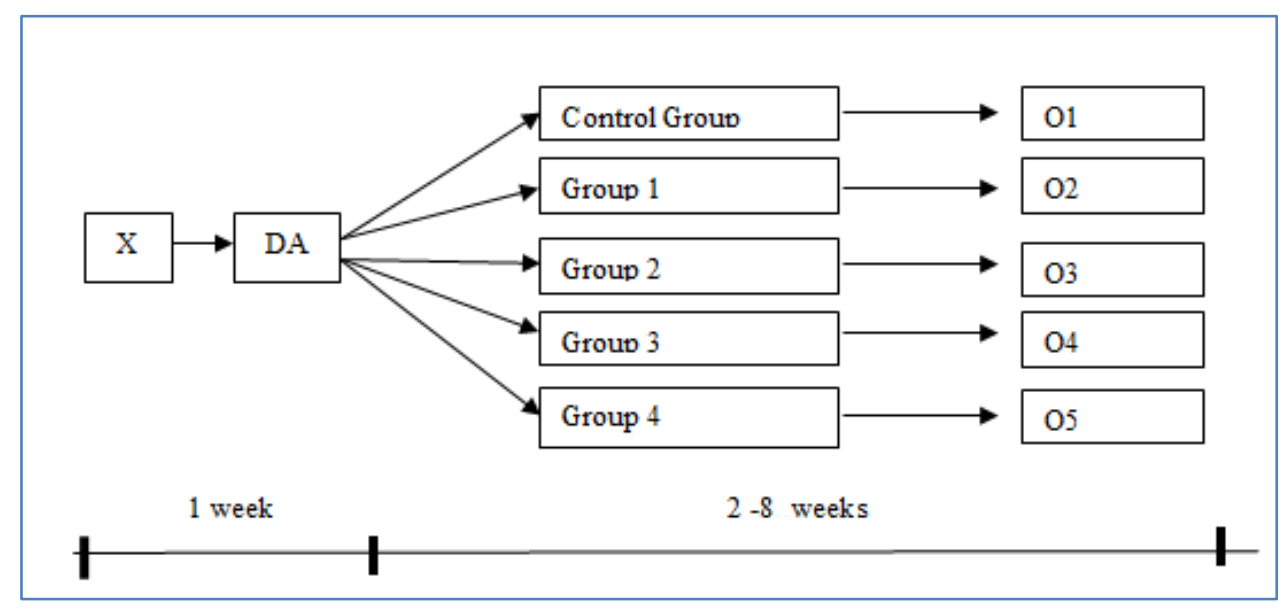

Fig-1: The scheme of the study

\begin{tabular}{|c|c|}
\hline $\mathrm{X}=$ Adaptation time & \multirow{2}{*}{$\begin{array}{l}\text { Every group gets one (1) additional mouse } \\
\text { for replacing mice which die during the study } \\
\text { period. }\end{array}$} \\
\hline DA = Time Allocation into 4 groups,e.g. & \\
\hline Control Group = group of mice without halothane & O1 = Output from the group control \\
\hline \multirow{4}{*}{$\begin{array}{l}\text { Group } 1=\text { exposure to } 0,011 \mathrm{mg} / \text { weight halothane } 3 \text { hours daily for two (2) } \\
\text { weeks. }{ }^{37} \text { The dose is less than the maximum dose for mice }(0,03) \text { because the } \\
\text { researcher doesn't know how much halothane which is inhaled by medical person. }\end{array}$} & $\mathrm{O} 2=$ Output from the group 1 \\
\hline & $\mathrm{O} 3=$ Output from the group 2 \\
\hline & $\mathrm{O} 4=$ Output from the group 3 \\
\hline & O5 = Output from the group 5 \\
\hline \multicolumn{2}{|l|}{ Group $2=$ exposure to $0,011 \mathrm{mg} /$ weight halothane 3 hours daily for four (4) weeks. } \\
\hline \multicolumn{2}{|l|}{ Group $3=$ exposure to $0,011 \mathrm{mg} /$ weight halothane 3 hours daily for six (6) weeks } \\
\hline $\begin{array}{l}\text { Group } 4=\text { exposure to } 0,011 \mathrm{mg} / \text { weight halothane } 3 \text { hours daily for six (6) weeks } \\
\text { followed by } 2 \text { weeks of free halothane }\end{array}$ & \\
\hline
\end{tabular}


Aisha Abduljalil Ashammam et al., Saudi J Biomed Res, Jan, 2022; 7(1): 1-20

The dose for halothane are $0.011 \mathrm{mg} /$ weight given 3 hours daily for 2 weeks, 4 week, 6 weeks and 6 weeks follow by 2 week halothane free. This research used fixed dose $(0.011 \mathrm{mg} /$ weight $)$ that is optimal dose of halothane on mice (Mark A at al., 2000). Optimal dose was characterized by activity of mice that was not obviously affected after halothane exposure. Different time of exposure mimics the working time of medical personal in operation room. Exposure of halothane about 3 hours because the averages of operation time by medical personals are 2-6 hours (data from medical person who work in the operation room) and researcher will use the median of average operation time. The median of the time is 3 hours. It had included $30 \mathrm{Balb} / \mathrm{C}$ mice (Male), in healthy condition and 6-10 weeks old, no infectious disease and the weight are between $29-$ 33 grams. They were excluded if the mice were diarrhea or show behavioral changes (e.g, do not eat/loose of appetite).

\section{DATA COLLECTION}

After terminated, the liver tissue of the mice were taken to do histopathology and immunohistochemistry examinations. The slides for those examinations were made at the pathology laboratory of RS. Dr. Sardjito Yogyakarta and read at the pathology laboratory of RSUP Dr. Kariyadi Semarang. Adaptation time was done in one day to prepare the mice, which are weighing, examining the health status, and helping the mice to adapt with new environment. The dose for halothane was $1.2 \mathrm{ml}$ per cage, given 3 hours daily for 2 weeks, 4 week, 6 weeks and 6 weeks followwed by 2 week halothane free. The halothane was put on a plate for each cage then placed inside. The halothane used was liquid halothane manufactured by Nicholas Piramal India Limited. Since halothane is an inhalation anesthetic that can evaporate easily at room temperature, we just put it on a plate and keep inside of the cages and let the mice inhale it for 3 hours each day.

After halothane exposure for 2 weeks, the mice from the Group 1 were terminated. The liver were taken and placed onto pure formalin for 24 hours, then processed by making parafin block. This procedure is standart procedure to take the liver organ. The tissue on this parafin block was sliced using microtom. HE staining was performed as regular staining to explore the tissue changes and immunohistochemistry staining was undertaken to explore the cytochrome P450 in the liver by using cytochrome P450 2E1 antibody.

\section{STATISTICAL DATA ANALYSIS}

Data collected from observation of liver cells changes and cytochrome P450 changes were descriptively analysed by counting the standard deviation and median. Numbers of liver cells changes and cytochrome $\mathrm{P} 450$ changes of each group were showed in box-plot graph. Shapiro-Wilk test was performed to test the data normality. Subsequently, the hypothesis test was conducted to find whether there is any difference of liver cells and cytochrome P450 changes between the control group and the experimental group with different time of halothane exposure by Kruskal-Wallis test. If the difference was significant post hoc analysis was carried out by MannWhitney test. All the analysis were done using SPSS version 12.0 .

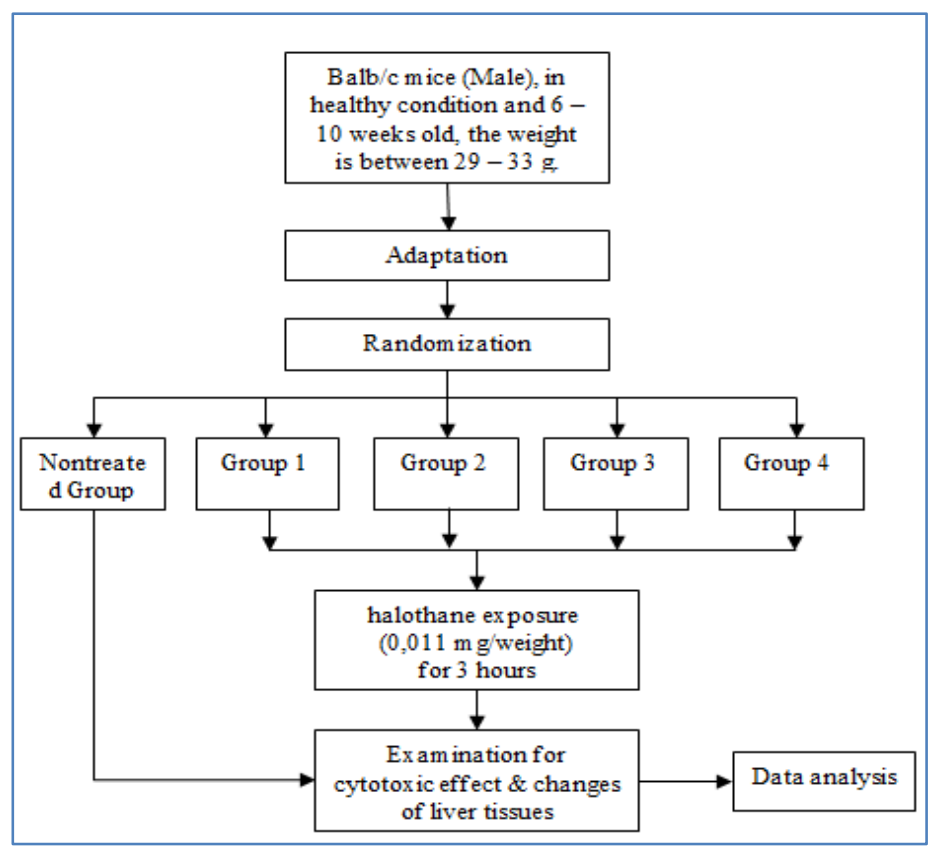

Fig-2: Flow chart of the study 
Aisha Abduljalil Ashammam et al., Saudi J Biomed Res, Jan, 2022; 7(1): 1-20

RESULT

Result of counting tissue changes from HE staining examination

Tissue changes were observed from $\mathrm{HE}$ staining examination with $1000 \mathrm{x}$ magnification in 10 fields from randomized choosing. The examiner counted the number of cells with nucleus changes (i.e, enlarge, karyorrhexis, and karyolitic). The results were expressed in percentage of abnormal cells per all cells counted on those fields. From total 30 mice, 30 livers of the mice were made into tissue slides as shown in Figure 3.

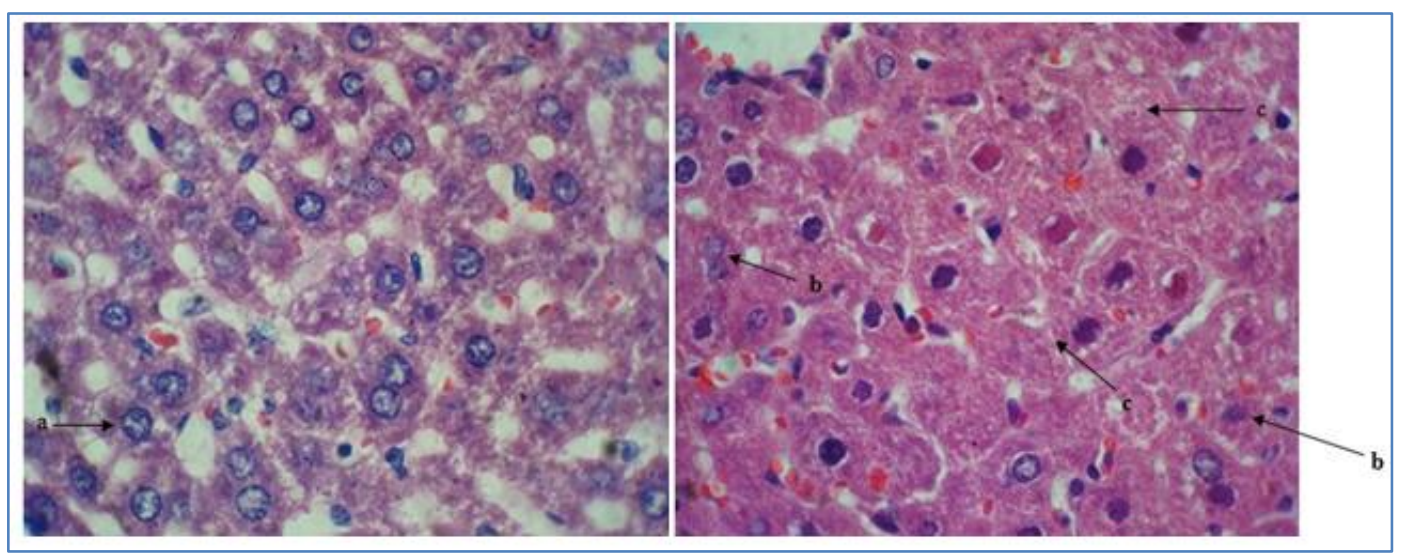

Fig-3: HE stains examination using 1000X magnification from: A. control group. The mean of abnormal cells percentage was $17.65 \%$. a: enlarge nucleus; B. group 3. b: karyorrhexis; c: karyolisis.

Table-1: Percentage of cell changes from HE staining examination

\begin{tabular}{|l|l|l|l|}
\hline Groups & Mean (\%) & Median (\%) & SD \\
\hline Control & 17.65 & 14.35 & 5.14 \\
\hline Group 1 & 40.93 & 40.39 & 1.71 \\
\hline Group 2 & 51.94 & 52.17 & 1.21 \\
\hline Group 3 & 61.22 & 60.79 & 0.59 \\
\hline Group 4 & 60.77 & 63.39 & 3.60 \\
\hline
\end{tabular}

Table 1 shows control group has the smallest percentage of nucleus changes (mean: 17.65\%) and group 3 has the highest percentage of nucleus changes (mean: 61.22). The following Figure 4 shows that box plot median percentage of nucleus liver changes in group 4 is higher than other groups.

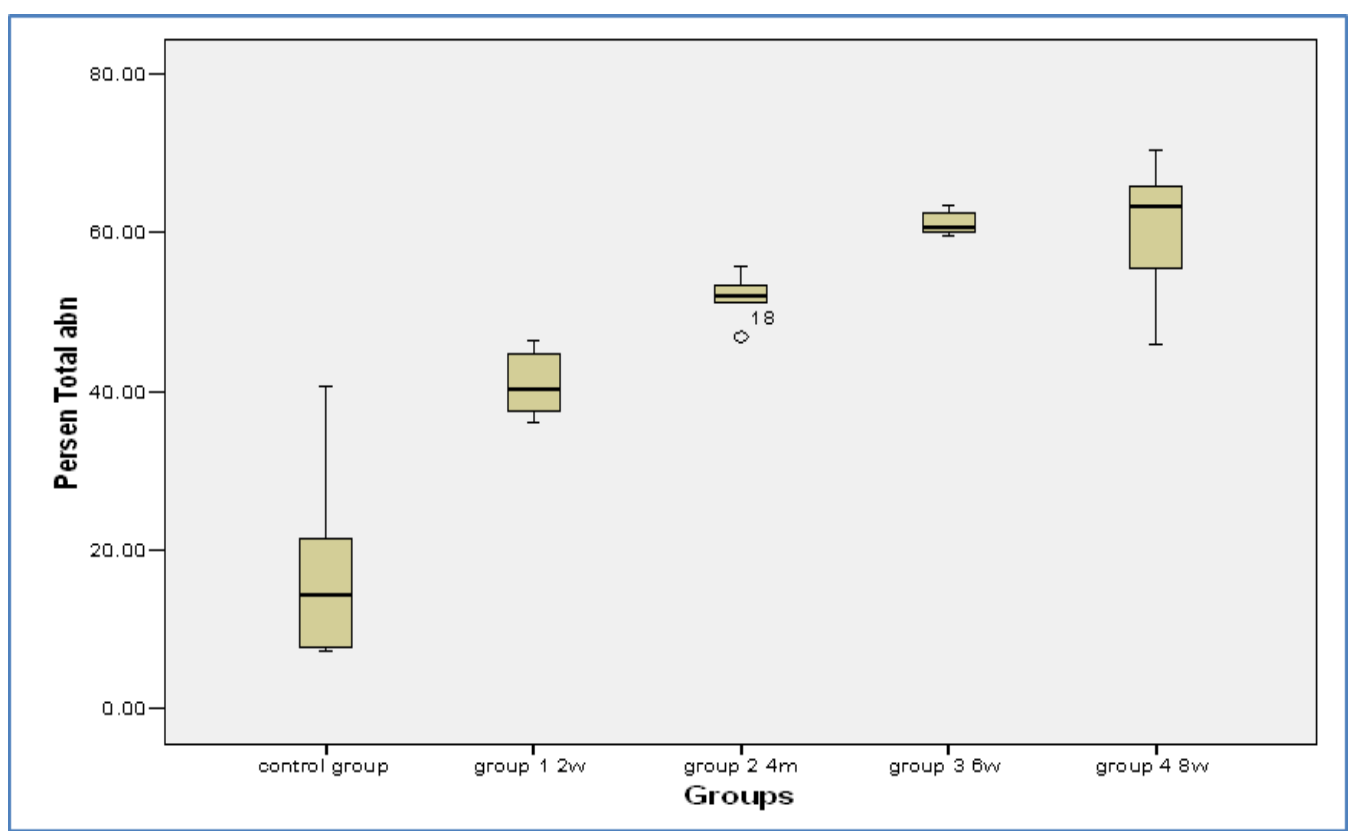

Fig-4: Box plot median percentage of BALB/c Mice liver cells' nucleus changes in control group, group 1, group 2, group 3 and group 4. 
Aisha Abduljalil Ashammam et al., Saudi J Biomed Res, Jan, 2022; 7(1): 1-20

The significance of these differences was revealed using statistic test. Using the Shapiro-Wilk test (test full result was attached on the appendix), we found that the data had normal distribution which can be seen in appendix 1, yet the data variant was not equal, so we could not perform one way Anova test to know the comparison among all groups. We performed KruskalWallis test and the result was statistically significant ( $p$ $=0.00$ ). Subsequently, we carried out Mann-Whitney test as Post Hoc test to know the statistic comparison between each group.
In Figure 4 we can see that the percentages of total abnormal cells were positively correlated with the time of exposure, thus, also with the dose of halothane. Interestingly, in the group 4, after six weeks halothane exposure followed by two weeks of free halothane, the mean of abnormal cells were less than group 3 which exposed by halothane for six weeks. However, overall abnormal cells were higher in group 4 which suggest the cells damage still continued regardless the cessation of halothane exposure. The comparison between these two groups was not statistically significant. Thus, we suggest that the liver damage may be irreversible.

Table-2: Comparison between each group (Post Hoc test). It is considered as statistically significant if $P<0.05$

\begin{tabular}{|l|l|l|l|l|l|}
\hline & Control group & Group 1 & Group 2 & Group 3 & Group 4 \\
\hline Control Group & - & $0.016^{*}$ & $0.004^{*}$ & $0.004^{*}$ & $0.004^{*}$ \\
\hline Group 1 & $0.016^{*}$ & - & $0.004^{*}$ & $0.004^{*}$ & $0.006^{*}$ \\
\hline Group 2 & $0.004^{*}$ & $0.004^{*}$ & - & $0.004^{*}$ & 0.078 \\
\hline Group 3 & $0.004^{*}$ & $0.004^{*}$ & $0.004^{*}$ & - & 0.522 \\
\hline Group 4 & $0.004^{*}$ & $0.006^{*}$ & 0.078 & 0.522 & - \\
\hline
\end{tabular}

Note: * statistically significant $(\mathrm{P}<0.05)$. The differences were statistically significant between each group, except between group 2 and group $4(\mathrm{p}=0.078)$ as well as between group 3 and group $4(\mathrm{P}=0.522)$

The differences were statistically significant between each group, except between group 2 and group $4(\mathrm{p}=0.078)$ as well as between group 3 and group $4(\mathrm{P}$ $=0.522)$ (table 2).

\section{Result of immunohistochemistry examination}

Expression of cytochrome P450 was observed using cytochrome P450 2E1 antibody. Examination and reading of the slides were done by counting the percentage of cytochrome P450 stained brown colour and giving score based on its intensity, 1 for weak staining, 2 for moderate staining and 3 for strong staining. Results were scored by multiplying the percentage of positive cells (P) by the intensity (I). Formula: $\mathrm{Q}=\mathrm{P}$ x I; Maximum score was 300. The complete results were attached in appendix 2.

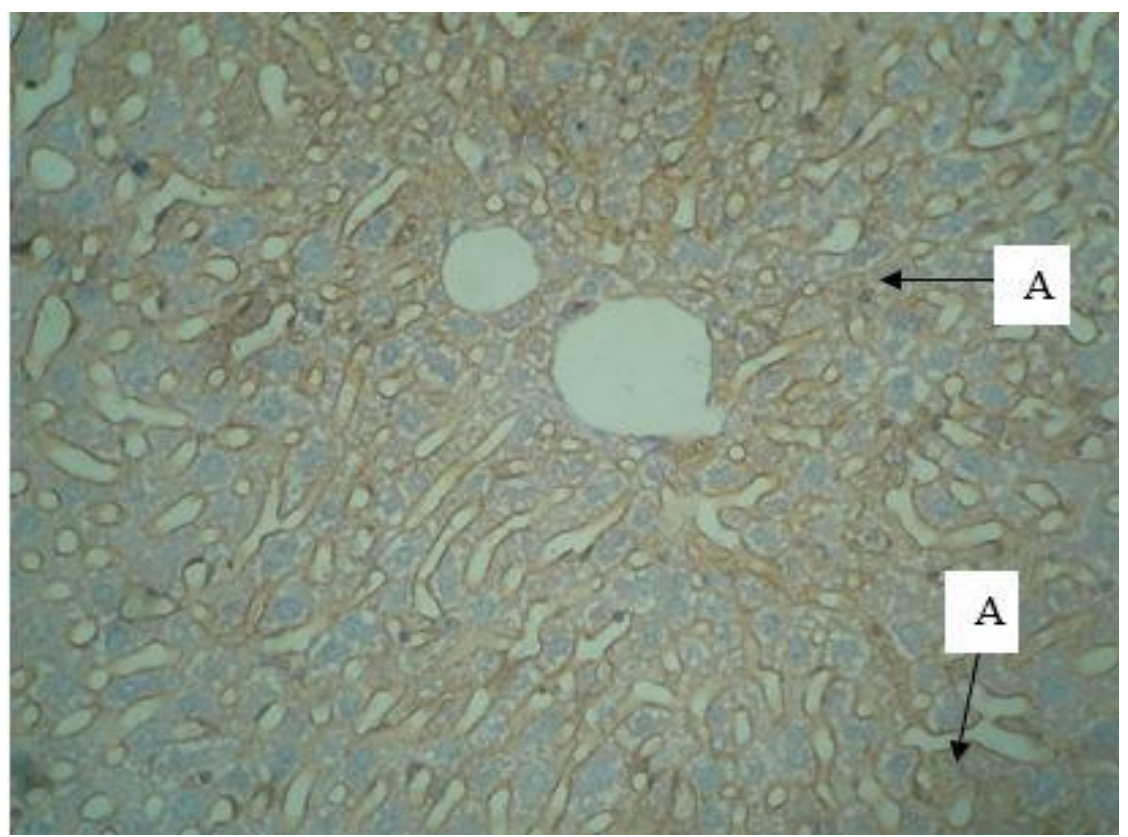

Fig-5: Morphology of P450 expression of the Balb c/ mice liver cells in control group, using 400X magnification. The cells were slightly brown coloured (A). 


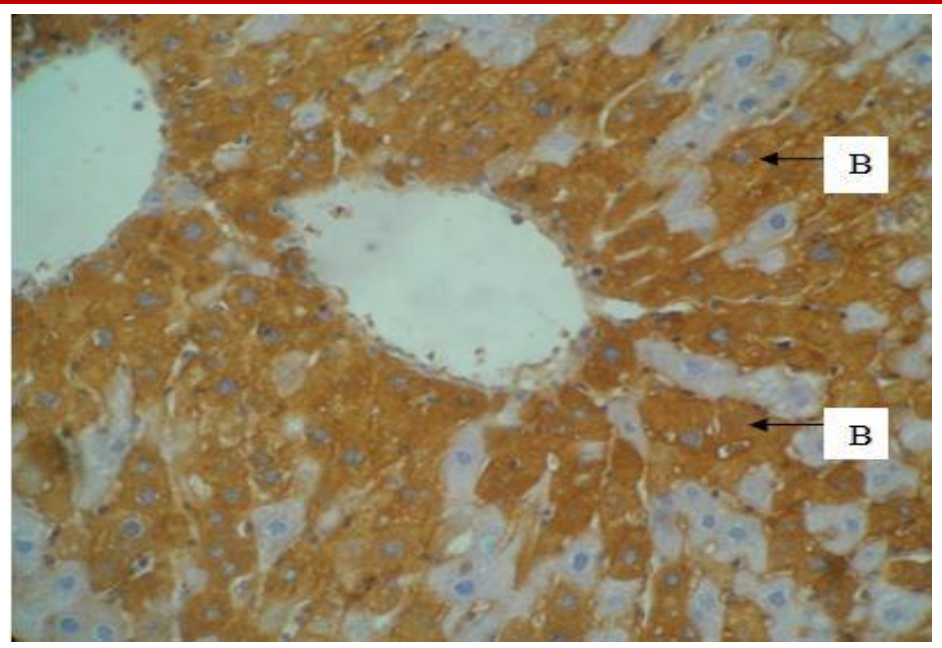

Fig-6: Morphology of $\mathbf{P 4 5 0}$ expression of the Balb c/ mice liver cells in group 3, using 400X magnification. The cells were intensely brown coloured (B).

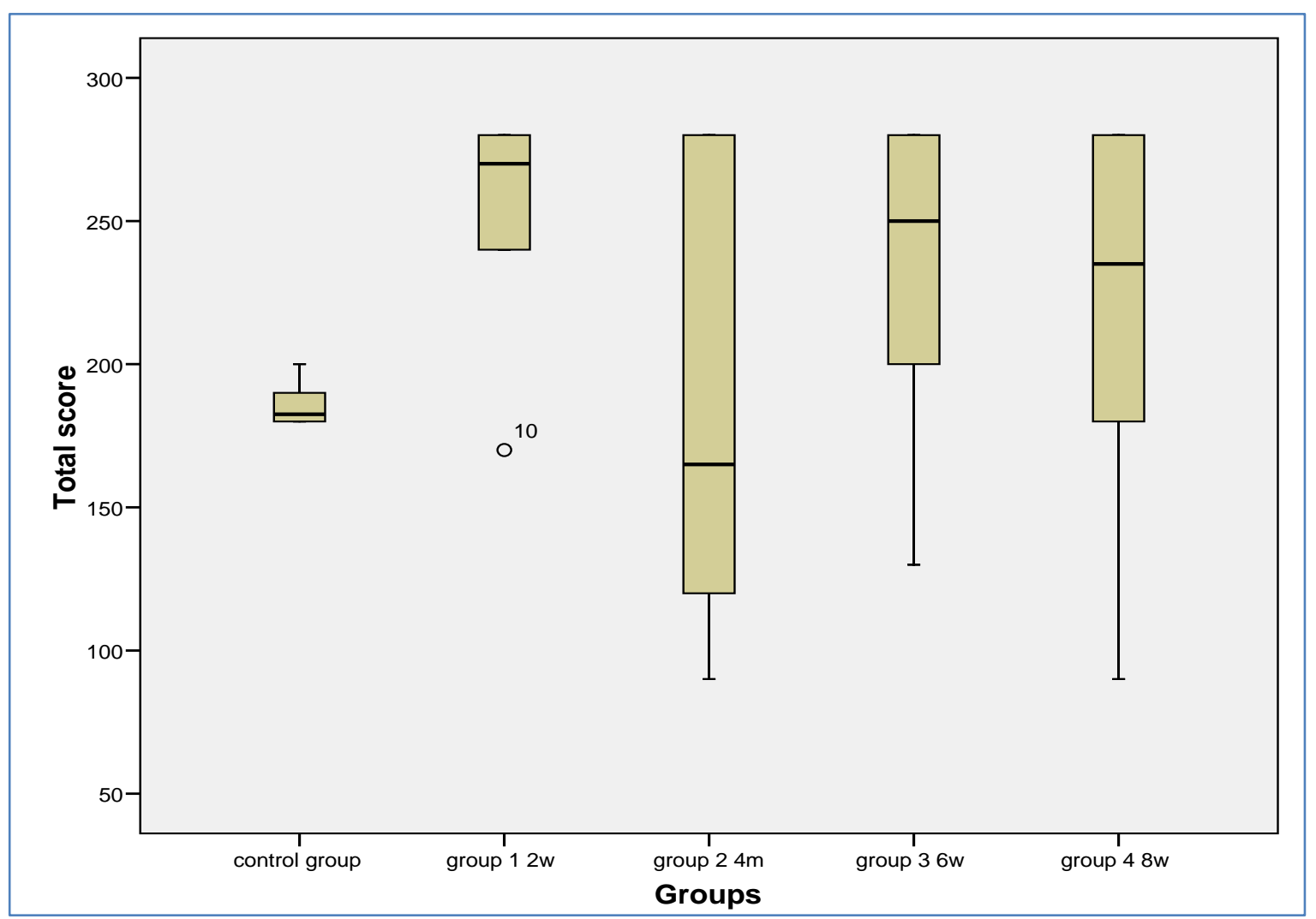

Fig-7: Box plot median percentage of cytochrome P450 expression in control group, group 1, group 2, group 3 and group 4

Table-3: P450 expression scoring from immunohistochemistry staining examination. Results were scored by multiplying the percentage of positive cells (P) by the intensity (I). Formula: $Q=P \times I$; Maximum score is 300 .

\begin{tabular}{|l|l|l|l|}
\hline Groups & Mean & Median & SD \\
\hline Control & 185.83 & 182.50 & 3.27 \\
\hline Group 1 & 251.67 & 270.00 & 17.59 \\
\hline Group 2 & 183.33 & 165.00 & 32.93 \\
\hline Group 3 & 231.67 & 250.00 & 24.82 \\
\hline Group 4 & 216.67 & 235.00 & 30.84 \\
\hline
\end{tabular}


The highest median score of cytochrome P450 expression was in group 1 while the lowest median belongs to group 2 (Table 3 ). Shapiro-Wilk test was performed and we found that the data distribution was not normal. Therefore, we did data transformation, yet it still had no normal distribution. To compare the cytochrome P450 expression among all groups, we used Kruskall-Wallis test. The result from this test was not statistically significant $(\mathrm{p}=0.266)$. Thus, we did not conduct Post Hoc test.

Given the results above, there was discrepancy between morphological change and P450 expression. The morphological change already presented earlier than the P450 changes. Therefore, we suggest that this morphological change (nucleus changes) can be used as early marker of liver damage and can be confirmed by liver function test. We also propose that the induction of cytochrome P450 might need longer time to present in the liver. Consequently, in this 8 weeks study the difference of cytochrome P450 expression was not presented in immunohistochemistry examination compare to those changes of cells' nucleus presented in the HE staining examination.

\section{DISCUSSION}

Medical person especially anesthetist, medical technician, and nurses need the best condition of operating room, i.e. there is adsorption tubes or diffusion dissenters for personal halothane concentration (Campbell et al., 1980). The total dosage of wasted halotane exposure depend on cumulative duration of the anesthetic time. Therefore, such medical personnel have a risk of tissue damages. This research aimed to identify and analyze the liver cells changes of halothane exposure to liver cells of Balb/C mice. We investigated the liver changes using $\mathrm{HE}$ staining and immunohistochemistry evaluation. The time of halothane exposure was modified as the independent variable. In HE staining evaluation, we examined the liver cells nucleus changes.

Furthermore, (Belge et al, 2000). used 30 male, non-inbred Mus musculus albino mice, 6-10 weeks old to investigate the effect of halothane anesthesia in different doses and a period of two weeks on glucose-6-phosphate dehydrogenase (G6PDH) activity of mouse liver. The mice were anesthetized with halothane using the same method with this research. The liver tissues showed eosinophil leukocyte and mononuclear inflammatory cell infiltration on portal tracts. Cloudy degenerations, congestions, microand macro vesicular fatty degeneration, spotty necrosis and centrilobular necrosis of the parenchymal cells were observed. They did not statistically test those findings. In this research, we counted the abnormal nucleus cells which could reflect cell damage.
From counting the abnormal cells through HE staining examination, we found that control group has the smallest percentage of nucleus changes (mean: $17.65 \%$ ) and group 3 has the highest percentage of nucleus changes (mean: 61.22). Total abnormal cells were positively correlated with the time of exposure. Interestingly, in the group 4, after six weeks halothane exposure followed by two weeks of free halothane, the mean of abnormal cells were less than group 3 which exposed by halothane for six weeks. However, overall abnormal cells were higher in group 4 which suggest the cells damage still continued regardless the cessation of halothane exposure. The comparison between these two groups was not statistically significant. Thus, we suggest that the liver damage may be irreversible.

Mechanisms of halothane toxicity are idiosyncratic reaction, immune allergic type, and the protein adducts formed in the initial toxic reaction provide the hapten for the formation of antibodies which augments damage on re-exposure. Up to onethird of inhaled halothane may be oxidatively metabolized by cytochrome P450 2E1 and 2A6. Trifluoro acetyl chloride, which has a strong ability to acetylate liver proteins, is formed during the synthesis of trifluoroacetic acid (TFA). Only a small amount $(\sim \% 1)$ of halothane is metabolized through the reductive pathway by cytochrome P450 2A6 and 3A4. This pathway is favored under hypoxic conditions, resulting in the release of bromide and fluoride ions and in the formation of other volatile organic metabolites (Hubbard et al, 2009). The release of these ions damage membrane integrity of cells and results in fatty change, acute yellow atrophy and widespread centrilobular hepatocellular necrosis that is indistinguishable from fulminant viral hepatitis.

Two types of halothane-mediated hepatotoxicity have been defined. The first type, type I, is a mild, self-limited postoperative hepatotoxicity, with a mild form of hepatocellular injury that can be observed in about $20 \%$ of halothane -treated patients. The mild hepatic injury is assumed to result from the direct action of halothane on the liver cells. The second type of halothane-mediated hepatotoxicity is type IIhalothane hepatitis. The incidence of this type of hepatotoxicity after halothane administration is one case per 10000-30000 adult patients. The probable mechanism is most likely an immune-mediated hepatotoxicity; antibodies are against modified liver microsomal proteins on hepatocyte surfaces (Wenker, 1999).

Sufficient tissue perfusion and oxygenation are vital for all metabolic processes in cells and the major influencing factor of tissue repair and resistance to infectious organisms. A concept covering both oxygen deliveries, tissue oxygen transport and oxygen 
Aisha Abduljalil Ashammam et al., Saudi J Biomed Res, Jan, 2022; 7(1): 1-20

consumption of the cells could be named tissue oxygen perfusion. In hepatic hypoxia, reductive pathway may metabolize halothane. Thus, halothane has reputation as liver toxin. In other hand, some believe that hepatic dysfunction after the administration of halothane and other anesthetics is related to global or surgical effects on liver perfusion rather than to the agent itself (Rahimzadeh et al, 2014).

The phenotype can be distinguished by the actual activity or the amount of the expressed CYP enzyme. The genotype, however, is determined by the individual DNA sequence. Since human has two sets of chromosomes, that mean the same genotype enables different phenotypes. Depending on the metabolic activity (phenotype), three major cathegories of metabolizers are separated: extensive metabolizer (normal), poor metabolizer, and ultra-rapid metabolizer (increased metabolism of xenobiotics). However, until recently there is no published evidence of CYP2E1, CYP2A6, and CYP3A4 genetic polymorphism that correlate with halothane metabolism (Daly, 2003; Varkey et al, 2004).

(Spracklin et al, 2003) conducted a research to test the hypotheses that disulfiram prevents halothanedependent protein trifluoroacetylation in vivo, and that TFA represents a biomarker for hepatic protein trifluoroacetylation. (Wenker, 1999) using rats pretreated with isoniazid (CYP2E1 induction), isoniazid followed by disulfiram (CYP2E1 inhibition), or nothing (controls), then anesthetized with halothane or nothing (controls), plasma and urine TFA were quantified by ion HPLC and hepatic microsomal TFA-proteins were analyzed by Western blot. He revealed that CYP2E1 induction increased both TFA and TFA-protein formation compared with uninduced halothane-treated rats.

Other researchers tried to determine concentrations of wasted halothane in operating rooms and investigated the effect of halothane pollution on liver functions of exposed personnel (MS et al, 2018; Nwobi et al, 2013; Prokes et al, 2009). They examined liver function test of 191 operating room personnel. Average concentration of waste halothane detected in examined surgical theaters has remained under TLV for halothane of $40 \mathrm{mg} / \mathrm{m} 3$ (4.9 ppm). Analyses showing the status of hepatic cell membrane (AST, ALT, LDH) revealed that average concentrations of all three parameters were significantly higher in the exposed medical personnel than in the control group.

In this study, we examined the cytochrome P450 2E1 expression in mice liver cells after halothane exposure using immunohistochemistry. We did not directly count the amount of TFA since Cytochrome $\mathrm{P} 450$ 2E1 (CYP2E1) is a major catalyst in the formation of trifluoro acetylated proteins; however, our result was not statistically significant. There are some factors that can influence the result of immunohistochemistry examination.

These factors can be divided into preanalytical, analytical and postanalytical factors. The pre-analytical factors include optimal preservation of the antigenic epitope. IHC can be affected by the duration of anoxia at surgery, time gap between resection to fixation, the type of fixative, the duration in the fixative, the size of the tissue, the thickness, and whether freezing was done. Finally, the quality of reagents such as the company, the batch, and the shelflife of antibodies can affect the kind of result obtained. Of these, optimal fixation is of special interest because it is a critical yet manageable step (Jambhekar et al, 2008).

The analytical factors include the various techniques used for antigen retrieval namely heat, microwaving, pressure cooking, trypsin digestion, autoclaving with different buffers etc. Proper endogenous peroxidase blocking is vital to prevent background staining. Further, whether an autostainer is being used or the staining is done by hand will influence the end result. The biochemical process involved is important, for example the relatively recent "catalyzed signal amplification" method is considered more sensitive than avidin-biotin or extra avidin methods.

The postanalytical (interpretative) factor is the actual interpretation of the IHC result by the surgical pathologist. Several large studies have addressed the issue of inter and intra-observer errors. The positive or the negative interpretation has several subtle nuances which only a busy practitioner of IHC will realize. Suffice it to say a combination of several observations such as intensity, quantity and localization of the IHC reaction and visualization of the immunostaining in the lesional cells - as opposed to the immuno reaction seen in normal tissues, reactive tissues and other 'bystanders' (often referred to as "background" staining) - are features vital to the final interpretation. Nevertheless the lack of a prescribed threshold level for interpreting a reaction as positive leaves immense scope for inter and intra observer errors. Finally, whatever the interpretation - it is the integration of the information obtained from the IHC test in the histopathologic picture is what matters most in the final interpretation.

Regardless of those factors, we propose that this non-significant difference of the cytochrome P450 (2E1) expression of the experiment groups compared with the control group was because it was analyzed in the liver tissue. It is possible when it analyzed in the serum/plasma, the result would be different. 
Aisha Abduljalil Ashammam et al., Saudi J Biomed Res, Jan, 2022; 7(1): 1-20

Furthermore, each mice probably has different metabolic activity (phenotype), those are: extensive metabolizer (normal), poor metabolizer, and ultra-rapid metabolizer (increased metabolism of xenobiotics), that in turn influence the expression of cytochrome P450.

This study has several limitations. First, it was difficult to design cages size that resembled the proportion of operating room and the halothane wasted. It was also difficult to make sure that every mouse got the same dose one and another since we did not control the air circulation. Finally, the acute effect of halothane administration intravenously when terminated the mice did not taken into account whether it would cause acute effect on the liver cells or not. It may explain why enlarged nucleus in the control group was found.

\section{CONCLUSSION}

The influences of $0.011 \mathrm{mg} / \mathrm{kg}$ halothene with different time exposure to Balb/c mice liver cell changes were:

1- There were statistically significant differences of abnormal changes in the liver cell nucleus of experiment groups with different time of halothane exposure $(p=0.000)$ compare to control group. The nucleus changes were gradually increased with the time of exposure.

2- There was no statistically significant difference of cytocrome P450 expressions of experiment groups with different time of halothane exposure $(p=$ 0.266) compare to control group.

\section{SUGGESTION}

Given the result above, limiting the exposure time of halothane for medical personels less than two weeks in the operating room is relatively simple measure to prevent halothane-induced liver cells changes that lead to liver disfungsion. Considering the side effects of halothane, whenever it is possible, I suggest to use other agents that has least side effects with regard to availability and its cost effectiveness. Further study about the best interval time of operation using halothane for patients safety is needed.

\section{REFERENCE}

- Barash, P. G. (2009). Clinical anesthesia. Lippincott Williams \& Wilkins.

- Bednarski, R. M. (2009). Anesthetic Equipment. Equine Anesthesia, 2, 315-331. https://doi.org/10.1016/B978-1-4160-23265.00016-X

- $\quad$ Belge, E., Yuregir, G. T., \& Tuncer, I. (2000). The effect of halothane on the enzymatic activity of mouse liver and erythrocyte glucose-6-phosphate dehydrogenase. Turkish Journal of Medical Sciences, 30(3), 219-222.

- Campbell, D., Davis, P. D., Halliday, M. M., \& MCDONALD, I. (1980). Comparison of personal pollution monitoring techniques for use in the operating room. British Journal of Anaesthesia, 52(9), 885-892.

- Daly, A. K. (2003). Pharmacogenetics of the major polymorphic metabolizing enzymes. Fundamental \& Clinical Pharmacology, 17(1), 27-41.

- Eger, E. I. (2004). Characteristics of anesthetic agents used for induction and maintenance of general anesthesia. American Journal of HealthSystem Pharmacy, 61(suppl_4), S3-S10.

- Falahian, F. (2009). Halothane induced hepatitis (CME).

- Hubbard, A. K., Roth, T. P., \& Gandolfi, A. J. (2020). A Potential Role for Immunological Mechanisms in Halothane Hepatotoxicity. In Hepatotoxicology (pp. 647-665). CRC Press.

- Jambhekar, N. A., Chaturvedi, A. C., \& Madur, B. P. (2008). Immunohistochemistry in surgical pathology practice: a current perspective of a simple, powerful, yet complex, tool. Indian Journal of Pathology \& Microbiology, 51(1), 2-11. https://doi.org/10.4103/0377-4929.40382

- Klassen, C. D., \& Doull, J. (2001). The basic science of poisons. McGraw Hill, New York.

- Mark A. Suckow, D. V. M., Peggy Danneman, V. M. D., \& Cory Brayton, D. V. M. (2000). The Laboratory Mouse. CRC Press LLC. Boca Raton London New York Washington, D.C.

- Miller, A. L., Theodore, D., \& Widrich, J. (2020). Inhalational Anesthetic. StatPearls Publishing, Treasure Island (FL). Retrieved from http://europepmc.org/books/NBK554540

- $\quad$ MS, S., SA, F., LA, R., \& NM, H. (2018). Study of some health hazards among operating theater personnel due to exposure to anesthetic gases (PART I). Egyptian Journal of Occupational Medicine, 42(3), 303-326.

- Njoku, D., Laster, M. J., Gong, D. H., Eger, E. I., Reed, G. F., \& Martin, J. L. (1997). Biotransformation of halothane, enflurane, isoflurane, and desflurane to trifluoroacetylated liver proteins: association between protein acylation and hepatic injury. Anesthesia \& Analgesia, 84(1), 173-178.

- Nwobi, O. R. E. O. B. A. L. N., \& Adedapo, K. S. (2013). Effect of halothane on liver enzymes after general anaesthesia. Int J Biol Med Res, 4(1), 2772-2775.

- $\quad$ Pohl, L. R., Pumford, N. R., \& Martin, J. L. (1996). Mechanisms, chemical structures and drug metabolism. European Journal of Haematology, 57(S60), 98-104.

- $\quad$ Prokes, B., Mikov, I., \& Glavaski, M. (2009). The Effect of Occupational Exposure to Wasted Halothane on Liver Functions of Operating Room Personnel. Polish Journal of Environmental Studies, 18(5). 
Aisha Abduljalil Ashammam et al., Saudi J Biomed Res, Jan, 2022; 7(1): 1-20

- Rahimzadeh, P., Safari, S., Faiz, S. H. R., \& Alavian, S. M. (2014). Anesthesia for patients with liver disease. Hepatitis Monthly, 14(7).

- $\quad$ Spracklin, D. K., Emery, M. E., Thummel, K. E., \& Kharasch, E. D. (2003). Concordance between trifluoroacetic acid and hepatic protein trifluoroacetylation after disulfiram inhibition of halothane metabolism in rats. Acta Anaesthesiologica Scandinavica, 47(6), 765-770.

- Steffey, E. P., Mama, K. R., \& Brosnan, R. J.
(2015). Inhalation anesthetics. Veterinary Anesthesia and Analgesia, 297-331.

- Varkey, J., \& Kelepouris, A. (2004). Fulminant hepatic failure - A retrospective study in Urumqi, Xinjiang P.R. of China 1999-2004.

- Walton, B. (1978). Anaesthesia, surgery and immunology. Anaesthesia, 33(4), 322-348.

- Wenker, O. (1999). Review of currently used inhalation anesthetics: Part I. The Internet Journal of Anesthesiology, 3(2).

\section{APPENDIX}

Appendix 1

HE Staining Examination Result: Distribution of BALB/c mice nucleus liver cells changes in percents between control group and intervention groups.

\section{Descriptive}

\begin{tabular}{|c|c|c|c|c|c|}
\hline \multirow{3}{*}{$\begin{array}{l}\text { Persen Total } \\
\text { abn }\end{array}$} & \multirow{2}{*}{$\begin{array}{l}\text { Groups } \\
\text { control group }\end{array}$} & \multirow{2}{*}{\multicolumn{2}{|c|}{ Mean }} & \multirow{3}{*}{$\begin{array}{r}\text { Statistic } \\
\mathbf{1 7 . 6 5 5 0} \\
4.4373 \\
\end{array}$} & \multirow{3}{*}{$\begin{array}{r}\text { Std. Error } \\
5.14192\end{array}$} \\
\hline & & & & & \\
\hline & & 95\% Confidence Interval for Mean & Lower Bound & & \\
\hline & & & Upper Bound & 30.8727 & \\
\hline & & \multicolumn{2}{|l|}{$5 \%$ Trimmed Mean } & 16.9483 & \\
\hline & & \multicolumn{2}{|l|}{ Median } & 14.3550 & \\
\hline & & \multicolumn{2}{|l|}{ Variance } & 158.636 & \\
\hline & & \multicolumn{2}{|l|}{ Std. Deviation } & 12.59507 & \\
\hline & & \multicolumn{2}{|l|}{ Minimum } & 7.33 & \\
\hline & & \multicolumn{2}{|l|}{ Maximum } & 40.70 & \\
\hline & & \multicolumn{2}{|l|}{ Range } & 33.37 & \\
\hline & & \multicolumn{2}{|l|}{ Interquartile Range } & 18.55 & \\
\hline & & \multicolumn{2}{|l|}{ Skewness } & 1.492 & .845 \\
\hline & & \multicolumn{2}{|l|}{ Kurtosis } & 2.234 & 1.741 \\
\hline & group $12 \mathrm{w}$ & \multicolumn{2}{|l|}{ Mean } & 40.9250 & 1.70954 \\
\hline & & 95\% Confidence Interval for Mean & Lower Bound & 36.5305 & \\
\hline & & & Upper Bound & 45.3195 & \\
\hline & & \multicolumn{2}{|l|}{$5 \%$ Trimmed Mean } & 40.8883 & \\
\hline & & \multicolumn{2}{|l|}{ Median } & 40.3900 & \\
\hline & & \multicolumn{2}{|l|}{ Variance } & 17.535 & \\
\hline & & \multicolumn{2}{|l|}{ Std. Deviation } & 4.18750 & \\
\hline & & \multicolumn{2}{|l|}{ Minimum } & 36.04 & \\
\hline & & \multicolumn{2}{|l|}{ Maximum } & 46.47 & \\
\hline & & \multicolumn{2}{|l|}{ Range } & 10.43 & \\
\hline & & \multicolumn{2}{|l|}{ Interquartile Range } & 8.05 & \\
\hline & & \multicolumn{2}{|l|}{ Skewness } & .246 & .845 \\
\hline & & Kurtosis & & -1.930 & 1.741 \\
\hline & group $24 \mathrm{~m}$ & Mean & & 51.9400 & 1.21465 \\
\hline & & 95\% Confidence Interval for Mean & Lower Bound & 48.8176 & \\
\hline & & & Upper Bound & 55.0624 & \\
\hline & & 5\% Trimmed Mean & & 52.0028 & \\
\hline & & Median & & 52.1700 & \\
\hline & & Variance & & 8.852 & \\
\hline & & Std. Deviation & & 2.97528 & \\
\hline & & Minimum & & 46.88 & \\
\hline & & Maximum & & 55.87 & \\
\hline & & Range & & 8.99 & \\
\hline & & Interquartile Range & & 4.00 & \\
\hline & & Skewness & & -.751 & .845 \\
\hline & & Kurtosis & & 1.787 & 1.741 \\
\hline & group 3 6w & Mean & & 61.2200 & .59471 \\
\hline & & 95\% Confidence Interval for Mean & Lower Bound & 59.6912 & \\
\hline
\end{tabular}


Aisha Abduljalil Ashammam et al., Saudi J Biomed Res, Jan, 2022; 7(1): 1-20

\begin{tabular}{|c|c|c|c|c|c|}
\hline & & & Upper Bound & 62.7488 & \\
\hline & & \multicolumn{2}{|l|}{ 5\% Trimmed Mean } & 61.1794 & \\
\hline & & \multicolumn{2}{|l|}{ Median } & 60.7950 & \\
\hline & & \multicolumn{2}{|l|}{ Variance } & 2.122 & \\
\hline & & \multicolumn{2}{|l|}{ Std. Deviation } & 1.45674 & \\
\hline & & \multicolumn{2}{|l|}{ Minimum } & 59.72 & \\
\hline & & \multicolumn{2}{|l|}{ Maximum } & 63.45 & \\
\hline & & \multicolumn{2}{|l|}{ Range } & 3.73 & \\
\hline & & \multicolumn{2}{|l|}{ Interquartile Range } & 2.69 & \\
\hline & & \multicolumn{2}{|l|}{ Skewness } & .747 & .845 \\
\hline & & \multicolumn{2}{|l|}{ Kurtosis } & -.964 & 1.741 \\
\hline & group $48 \mathrm{w}$ & \multicolumn{2}{|l|}{ Mean } & 60.7683 & 3.60177 \\
\hline & & 95\% Confidence Interval for Mean & Lower Bound & 51.5097 & \\
\hline & & & Upper Bound & 70.0270 & \\
\hline & & \multicolumn{2}{|l|}{ 5\% Trimmed Mean } & 61.0609 & \\
\hline & & \multicolumn{2}{|l|}{ Median } & 63.3950 & \\
\hline & & \multicolumn{2}{|l|}{ Variance } & 77.836 & \\
\hline & & \multicolumn{2}{|l|}{ Std. Deviation } & 8.82250 & \\
\hline & & \multicolumn{2}{|l|}{ Minimum } & 45.84 & \\
\hline & & \multicolumn{2}{|l|}{ Maximum } & 70.43 & \\
\hline & & \multicolumn{2}{|l|}{ Range } & 24.59 & \\
\hline & & \multicolumn{2}{|l|}{ Interquartile Range } & 13.85 & \\
\hline & & \multicolumn{2}{|l|}{ Skewness } & -1.021 & .845 \\
\hline & & \multicolumn{2}{|l|}{ Kurtosis } & .700 & 1.741 \\
\hline
\end{tabular}

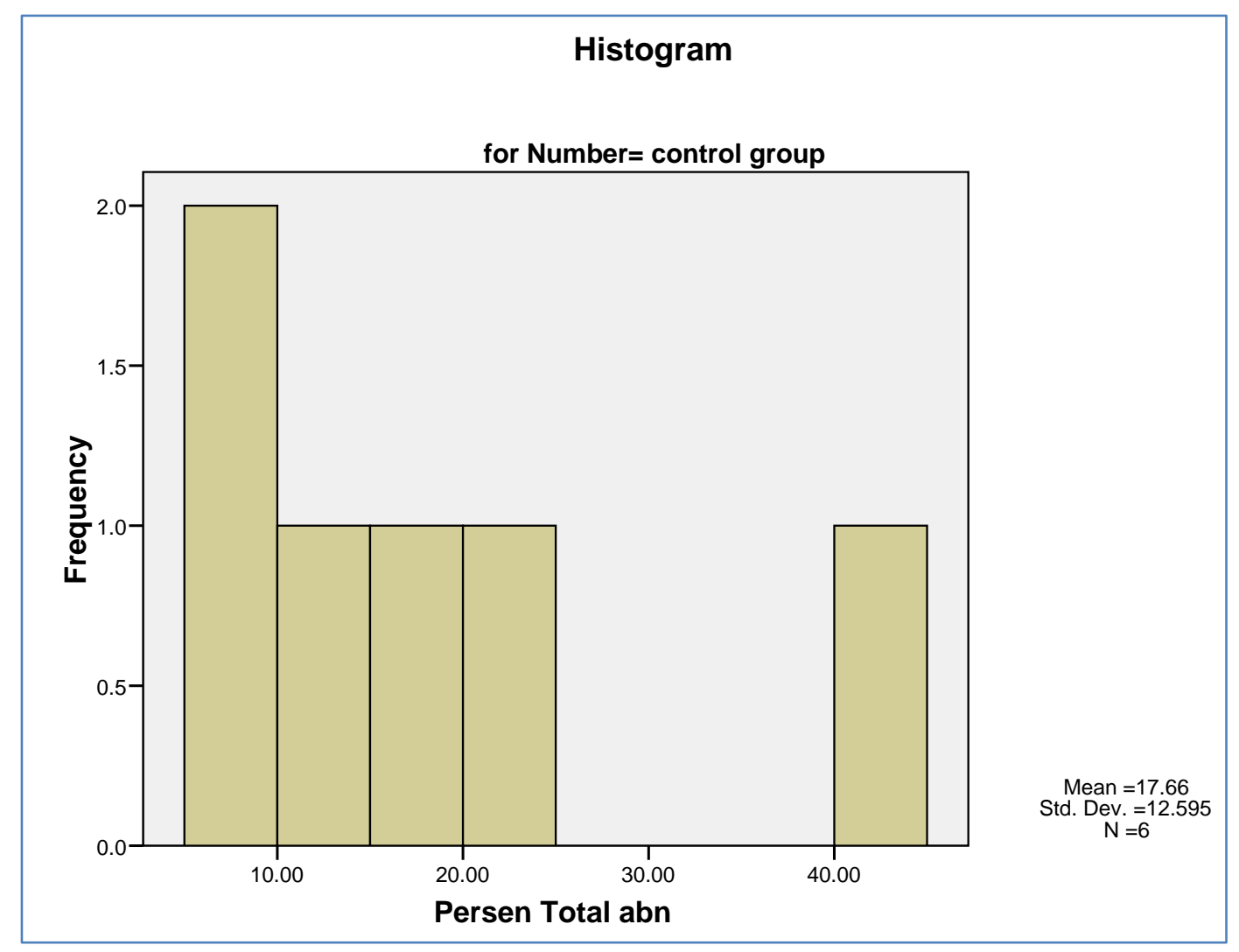



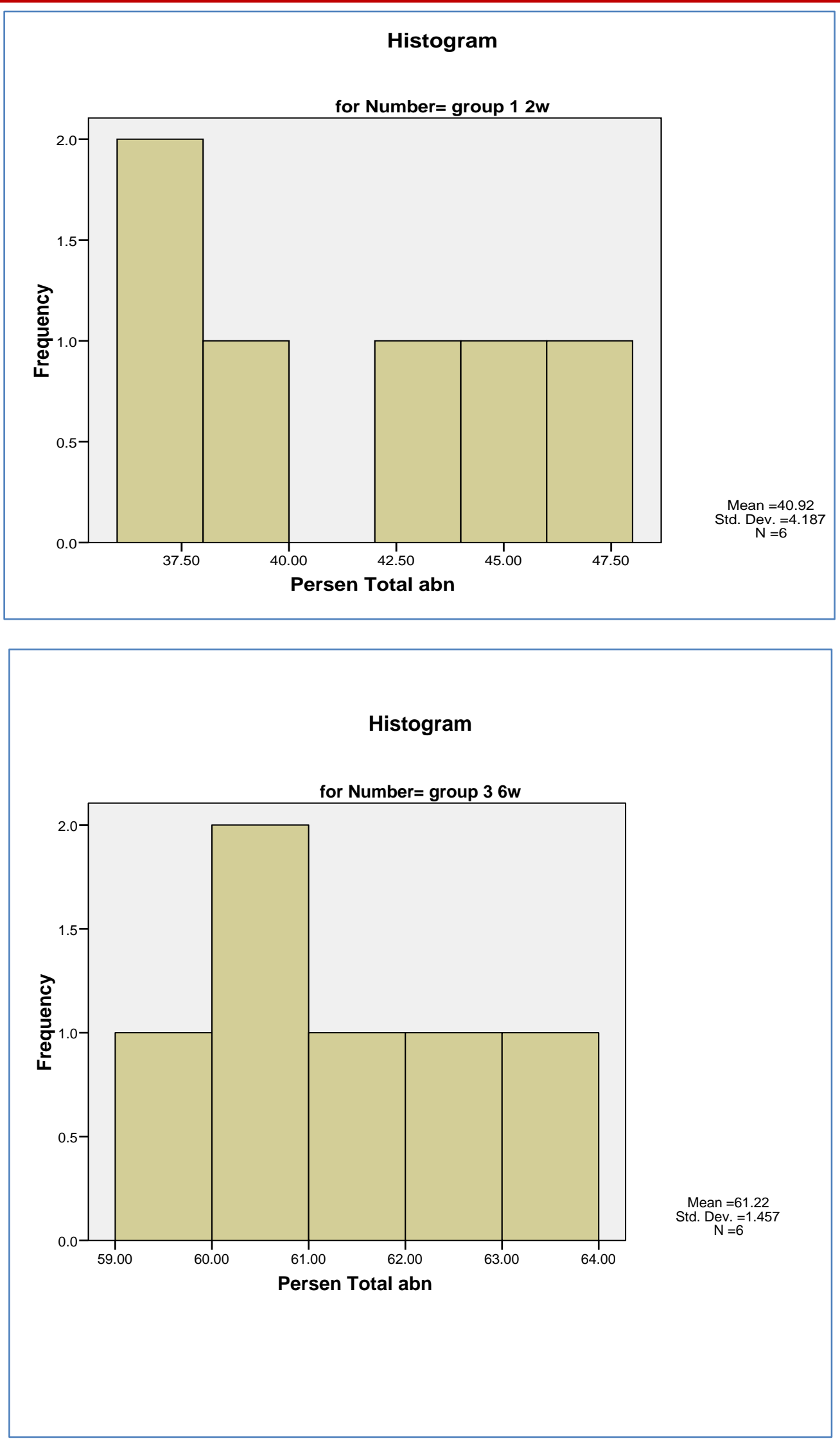

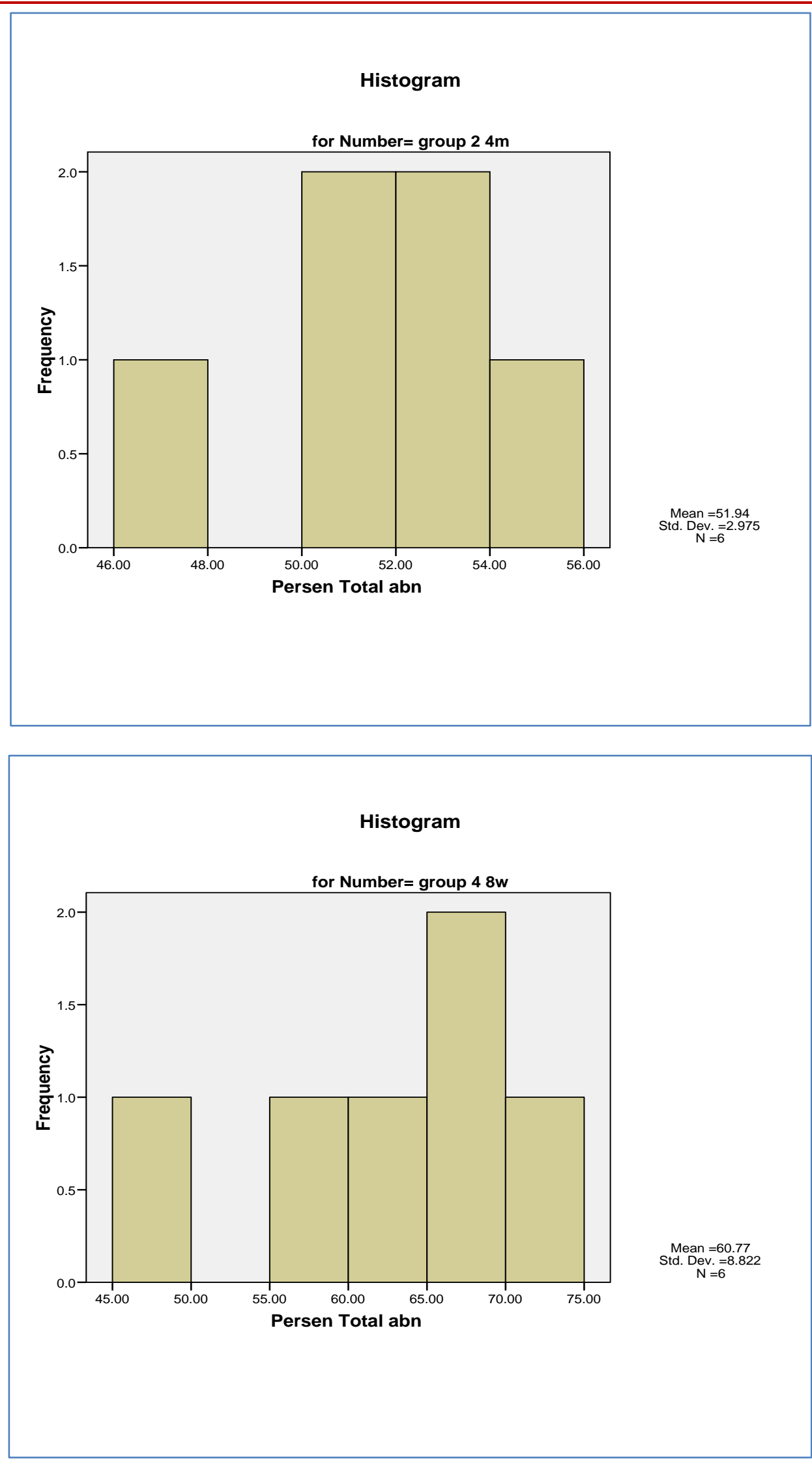

Box Plot control groups and four intervention groups 


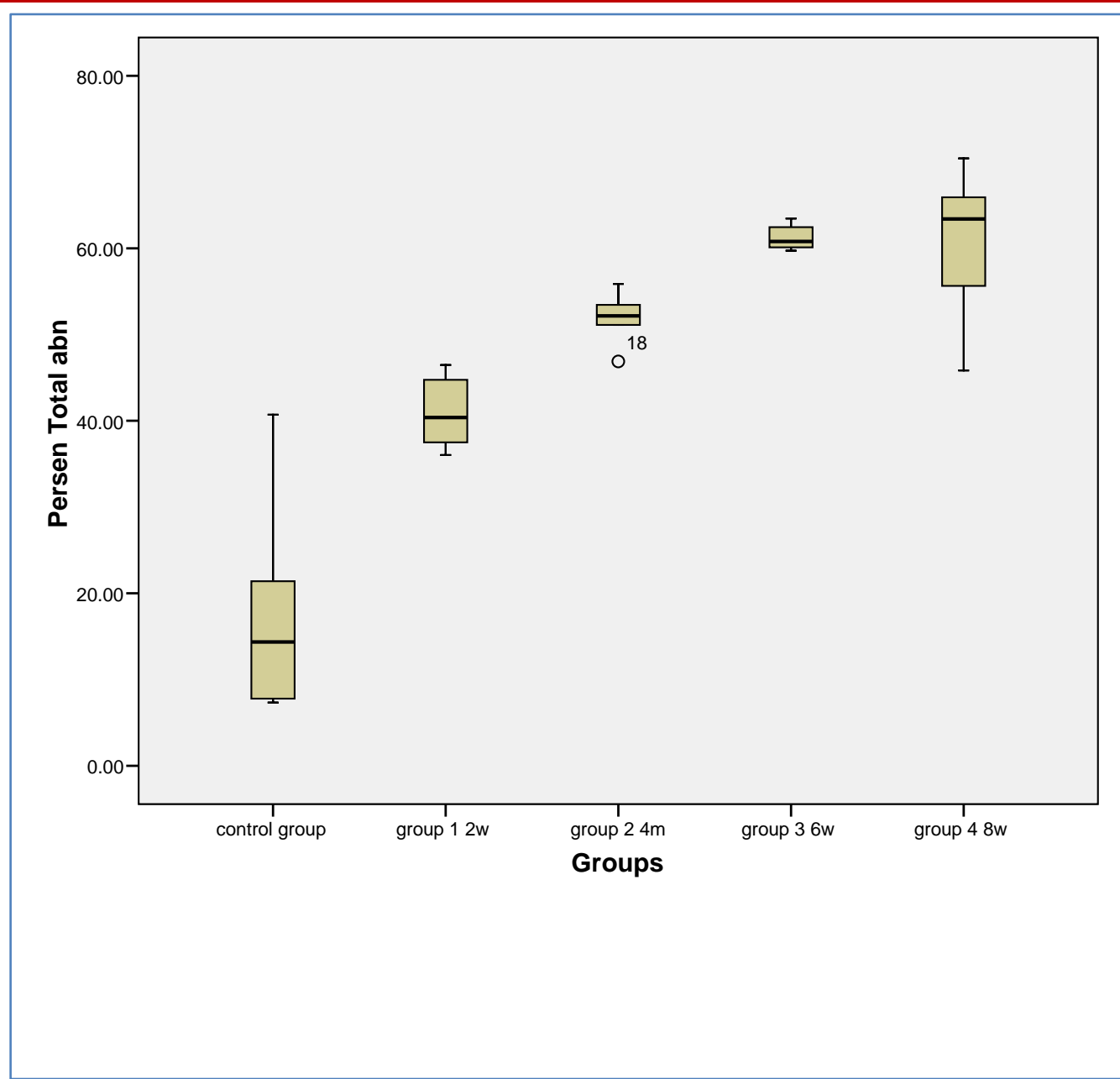

Tests of Normality

\begin{tabular}{|c|c|c|c|c|c|c|c|}
\hline & Groups & \multicolumn{3}{|c|}{ Kolmogorov-Smirnov(a) } & \multicolumn{3}{|c|}{ Shapiro-Wilk } \\
\hline & & Statistic & df & Sig. & Statistic & df & Sig. \\
\hline Persen Total abn & control group & .216 & 6 & $.200(*)$ & .844 & 6 & .139 \\
\hline & group $12 \mathrm{w}$ & 207 & 6 & $.200(*)$ & .934 & 6 & .615 \\
\hline & group $24 \mathrm{~m}$ & .223 & 6 & $.200(*)$ & .950 & 6 & .743 \\
\hline & group $36 \mathrm{w}$ & 209 & 6 & $.200(*)$ & .918 & 6 & .493 \\
\hline & group $48 w$ & .204 & 6 & $.200(*)$ & .929 & 6 & .569 \\
\hline
\end{tabular}

Kruskal-Wallis Test

Among all groups

Test Statistics (a,b)

\begin{tabular}{|c|c|}
\hline & Persen Total abn \\
\hline Chi-Square & 24.202 \\
\hline df & 4 \\
\hline Asymp. Sig. & .000 \\
\hline
\end{tabular}

a Kruskal Wallis Test

b Grouping Variable: Groups

Post Hoc Test

Mann-Whitney test
Between control group and group 1

Test Statistics(b)

\begin{tabular}{|c|c|}
\hline & Persen Total abn \\
\hline Mann-Whitney U & 3.000 \\
\hline Wilcoxon W & 24.000 \\
\hline Z & -2.402 \\
\hline Asymp. Sig. (2-tailed) & .016 \\
\hline $\begin{array}{c}\text { Exact Sig. [2*(1- } \\
\text { tailed Sig.) }\end{array}$ & $.015(\mathrm{a})$ \\
\hline
\end{tabular}

a Not corrected for ties.

b Grouping Variable: Groups 
Aisha Abduljalil Ashammam et al., Saudi J Biomed Res, Jan, 2022; 7(1): 1-20

Between control group and group 2

Test Statistics(b)

\begin{tabular}{|l|r|}
\hline & Persen Total abn \\
\hline Mann-Whitney U & .000 \\
\hline Wilcoxon W & 21.000 \\
\hline Z & -2.882 \\
\hline Asymp. Sig. (2-tailed) & .004 \\
\hline Exact Sig. [2*(1-tailed & $.002(\mathrm{a})$ \\
Sig.)] & \\
\hline
\end{tabular}

a Not corrected for ties.

b Grouping Variable: Groups

Between control group and group 3

Test Statistics(b)

\begin{tabular}{|c|c|}
\hline & Persen Total abn \\
\hline Mann-Whitney U & .000 \\
\hline Wilcoxon W & 21.000 \\
\hline Z & -2.882 \\
\hline Asymp. Sig. (2-tailed) & .004 \\
\hline $\begin{array}{c}\text { Exact Sig. [2*(1-tailed } \\
\text { Sig.)] }\end{array}$ & $.002(\mathrm{a})$ \\
\hline \multicolumn{2}{|c|}{ a Not corrected for ties. } \\
b Grouping Variable: Groups
\end{tabular}

Between control group and group 4

Test Statistics(b)

\begin{tabular}{|c|c|}
\hline & Persen Total abn \\
\hline Mann-Whitney U & .000 \\
\hline Wilcoxon W & 21.000 \\
\hline Z & -2.882 \\
\hline Asymp. Sig. (2-tailed) & .004 \\
\hline $\begin{array}{c}\text { Exact Sig. [2*(1-tailed } \\
\text { Sig.)] }\end{array}$ & $.002(\mathrm{a})$ \\
\hline
\end{tabular}

a Not corrected for ties.

b Grouping Variable: Groups

Between group 1 and group 2

Test Statistics(b)

\begin{tabular}{|c|c|}
\hline & Persen Total abn \\
\hline Mann-Whitney U & .000 \\
\hline Wilcoxon W & 21.000 \\
\hline Z & -2.882 \\
\hline Asymp. Sig. (2-tailed) & .004 \\
\hline $\begin{array}{c}\text { Exact Sig. [2*(1-tailed } \\
\text { Sig.)] }\end{array}$ & $.002(\mathrm{a})$ \\
\hline \multicolumn{2}{|c|}{ a Not corrected for ties. } \\
b Grouping Variable: Groups
\end{tabular}

Between group 1 and group 3 Test Statistics $(\mathbf{b})$

\begin{tabular}{|c|c|}
\hline & Persen Total abn \\
\hline Mann-Whitney U & .000 \\
\hline Wilcoxon W & 21.000 \\
\hline Z & -2.882 \\
\hline Asymp. Sig. (2-tailed) & .004 \\
\hline $\begin{array}{c}\text { Exact Sig. [2*(1-tailed } \\
\text { Sig.)] }\end{array}$ & $.002(\mathrm{a})$ \\
\hline
\end{tabular}

a Not corrected for ties.

b Grouping Variable: Groups
Between group 1 and group 4

Test Statistics(b)

\begin{tabular}{|c|c|}
\hline & Persen Total abn \\
\hline Mann-Whitney U & 1.000 \\
\hline Wilcoxon W & 22.000 \\
\hline Z & -2.722 \\
\hline Asymp. Sig. (2-tailed) & .006 \\
\hline $\begin{array}{c}\text { Exact Sig. [2*(1- } \\
\text { tailed Sig.)] }\end{array}$ & $.004(\mathrm{a})$ \\
\hline
\end{tabular}

a Not corrected for ties.

b Grouping Variable: Groups

Between group 2 and group 3

Test Statistics(b)

\begin{tabular}{|c|c|}
\hline & Persen Total abn \\
\hline Mann-Whitney U & .000 \\
\hline Wilcoxon W & 21.000 \\
\hline Z & -2.882 \\
\hline Asymp. Sig. (2-tailed) & .004 \\
\hline $\begin{array}{c}\text { Exact Sig. [2*(1- } \\
\text { tailed Sig.)] }\end{array}$ & $.002(\mathrm{a})$ \\
\hline
\end{tabular}

a Not corrected for ties.

b Grouping Variable: Groups

Between group 2 and group 4

Test Statistics(b)

\begin{tabular}{|c|c|}
\hline & Persen Total abn \\
\hline Mann-Whitney U & 7.000 \\
\hline Wilcoxon W & 28.000 \\
\hline $\mathrm{Z}$ & -1.761 \\
\hline Asymp. Sig. (2-tailed) & .078 \\
\hline $\begin{array}{c}\text { Exact Sig. [2*(1- } \\
\text { tailed Sig.)] }\end{array}$ & $.093(\mathrm{a})$ \\
\hline
\end{tabular}

a Not corrected for ties.

b Grouping Variable: Groups

Between group 3 and group 4

Test Statistics(b)

\begin{tabular}{|c|c|}
\hline & Persen Total abn \\
\hline Mann-Whitney U & 14.000 \\
\hline Wilcoxon W & 35.000 \\
\hline Z & -.641 \\
\hline Asymp. Sig. (2-tailed) & .522 \\
\hline $\begin{array}{c}\text { Exact Sig. [2*(1- } \\
\text { tailed Sig.)] }\end{array}$ & $.589(\mathrm{a})$ \\
\hline
\end{tabular}

a Not corrected for ties.

b Grouping Variable: Groups

\section{Appendix 2}

Immunohistochemistry Staining Examination Result: Distribution of BALB/c mice cytochrome P450 expression in percents between control group and intervention groups. 
Aisha Abduljalil Ashammam et al., Saudi J Biomed Res, Jan, 2022; 7(1): 1-20

Description

\begin{tabular}{|c|c|c|c|c|c|}
\hline \multirow{2}{*}{ Total score } & \multirow{2}{*}{$\begin{array}{l}\text { Groups } \\
\text { control group } \\
\end{array}$} & \multicolumn{2}{|l|}{ Mean } & \multirow{2}{*}{$\begin{array}{r}\text { Statistic } \\
185.83 \\
\end{array}$} & \multirow{2}{*}{$\begin{array}{r}\text { Std. Error } \\
3.270 \\
\end{array}$} \\
\hline & & Mean & & & \\
\hline & & $\begin{array}{l}95 \% \text { Confidence } \\
\text { Interval for Mean }\end{array}$ & Lower Bound & 177.43 & \\
\hline & & & Upper Bound & 194.24 & \\
\hline & & \multicolumn{2}{|l|}{ 5\% Trimmed Mean } & 185.37 & \\
\hline & & \multicolumn{2}{|l|}{ Median } & 182.50 & \\
\hline & & \multicolumn{2}{|l|}{ Variance } & 64.167 & \\
\hline & & \multicolumn{2}{|l|}{ Std. Deviation } & 8.010 & \\
\hline & & \multicolumn{2}{|l|}{ Minimum } & 180 & \\
\hline & & \multicolumn{2}{|l|}{ Maximum } & 200 & \\
\hline & & \multicolumn{2}{|l|}{ Range } & 20 & \\
\hline & & \multicolumn{2}{|l|}{ Interquartile Range } & 13 & \\
\hline & & \multicolumn{2}{|l|}{ Skewness } & 1.354 & .845 \\
\hline & & \multicolumn{2}{|l|}{ Kurtosis } & 1.240 & 1.741 \\
\hline & group $12 \mathrm{w}$ & \multicolumn{2}{|l|}{ Mean } & 251.67 & 17.591 \\
\hline & & $\begin{array}{l}95 \% \text { Confidence } \\
\text { Interval for Mean }\end{array}$ & Lower Bound & 206.45 & \\
\hline & & & Upper Bound & 296.89 & \\
\hline & & \multicolumn{2}{|l|}{ 5\% Trimmed Mean } & 254.63 & \\
\hline & & \multicolumn{2}{|l|}{ Median } & 270.00 & \\
\hline & & \multicolumn{2}{|l|}{ Variance } & 1856.667 & \\
\hline & & \multicolumn{2}{|l|}{ Std. Deviation } & 43.089 & \\
\hline & & \multicolumn{2}{|l|}{ Minimum } & 170 & \\
\hline & & Maximum & & 280 & \\
\hline & & Range & & 110 & \\
\hline & & Interquartile Rang & & 58 & \\
\hline & & Skewness & & -1.790 & .845 \\
\hline & & Kurtosis & & 3.180 & 1.741 \\
\hline & group $24 \mathrm{~m}$ & Mean & & 183.33 & 32.931 \\
\hline & & $\begin{array}{l}\text { 95\% Confidence } \\
\text { Interval for Mean }\end{array}$ & Lower Bound & 98.68 & \\
\hline & & & Upper Bound & 267.98 & \\
\hline & & 5\% Trimmed Mea & & 183.15 & \\
\hline & & Median & & 165.00 & \\
\hline & & Variance & & 6506.667 & \\
\hline & & Std. Deviation & & 80.664 & \\
\hline & & Minimum & & 90 & \\
\hline & & Maximum & & 280 & \\
\hline & & Range & & 190 & \\
\hline & & Interquartile Rang & & 168 & \\
\hline & & Skewness & & .402 & .845 \\
\hline & & Kurtosis & & -1.821 & 1.741 \\
\hline & group $36 \mathrm{w}$ & Mean & & 231.67 & 24.822 \\
\hline & & $\begin{array}{l}95 \% \text { Confidence } \\
\text { Interval for Mean }\end{array}$ & Lower Bound & 167.86 & \\
\hline & & & Upper Bound & 295.47 & \\
\hline & & $5 \%$ Trimmed Mea & & 234.63 & \\
\hline & & Median & & 250.00 & \\
\hline & & Variance & & 3696.667 & \\
\hline & & Std. Deviation & & 60.800 & \\
\hline & & Minimum & & 130 & \\
\hline & & Maximum & & 280 & \\
\hline & & Range & & 150 & \\
\hline & & Interquartile Rang & & 98 & \\
\hline
\end{tabular}


Aisha Abduljalil Ashammam et al., Saudi J Biomed Res, Jan, 2022; 7(1): 1-20

\begin{tabular}{|r|l|r|r|r|}
\hline & \multicolumn{2}{|c|}{ Skewness } & -.995 & .845 \\
\hline & \multicolumn{2}{|l|}{ Kurtosis } & .114 & 1.741 \\
\hline & group 4 8w & Mean & 216.67 & 30.840 \\
\hline & $\begin{array}{l}\text { 95\% Confidence } \\
\text { Interval for Mean }\end{array}$ & Lower Bound & 137.39 & \\
\hline & & Upper Bound & 295.94 & \\
\hline & & 220.19 & \\
\hline & 5\% Trimmed Mean & 235.00 & \\
\hline & Median & 5706.667 & \\
\hline & Variance & 75.542 & \\
\hline & Std. Deviation & 90 & \\
\hline & Minimum & 280 & 190 & \\
\hline & Maximum & 123 & .845 \\
\hline & Range & -.993 & 1.741 \\
\hline
\end{tabular}

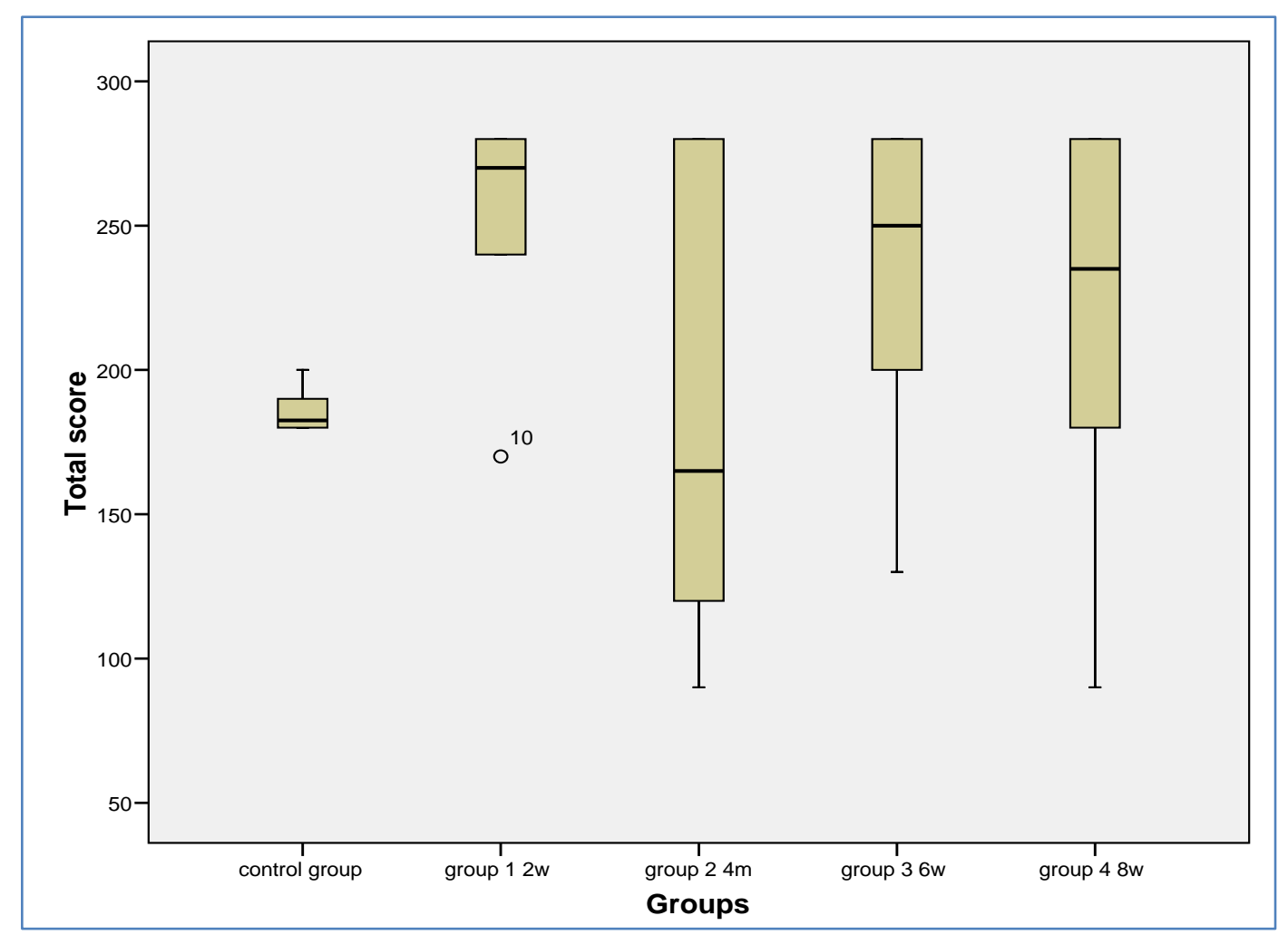

Tests of Normality

\begin{tabular}{|l|l|r|r|r|r|r|r|}
\hline & Groups & \multicolumn{3}{|c|}{ Kolmogorov-Smirnov(a) } & \multicolumn{2}{c|}{ Shapiro-Wilk } \\
\hline & & \multicolumn{1}{c|}{ Statistic } & \multicolumn{1}{c|}{ df } & \multicolumn{1}{c|}{ Sig. } & \multicolumn{1}{c|}{ Statistic } & \multicolumn{1}{c|}{ df } & \multicolumn{1}{c|}{ Sig. } \\
\hline Positive staining & control group & .319 & 6 & .056 & .683 & 6 & .004 \\
\hline & group 1 2w & .267 & 6 & $.200\left(^{*}\right)$ & .809 & 6 & .070 \\
\hline & group 2 4m & .294 & 6 & .114 & .843 & 6 & .138 \\
\hline & group 3 6w & .265 & 6 & $.200\left(^{*}\right)$ & .799 & 6 & .058 \\
\hline & group 4 8w & .277 & 6 & .165 & .825 & 6 & .097 \\
\hline
\end{tabular}

* This is a lower bound of the true significance.

a Lilliefors Significance Correction 
Aisha Abduljalil Ashammam et al., Saudi J Biomed Res, Jan, 2022; 7(1): 1-20

\section{Kruskal-Wallis}

Among groups

\section{Test Statistics(a,b)}

\begin{tabular}{|c|c|}
\hline & Total score \\
\hline Chi-Square & 5.216 \\
\hline df & 4 \\
\hline Asymp. Sig. & .266 \\
\hline
\end{tabular}

a Kruskal Wallis Test

b Grouping Variable: Groups

\section{Appendix 3}

Research Pictures

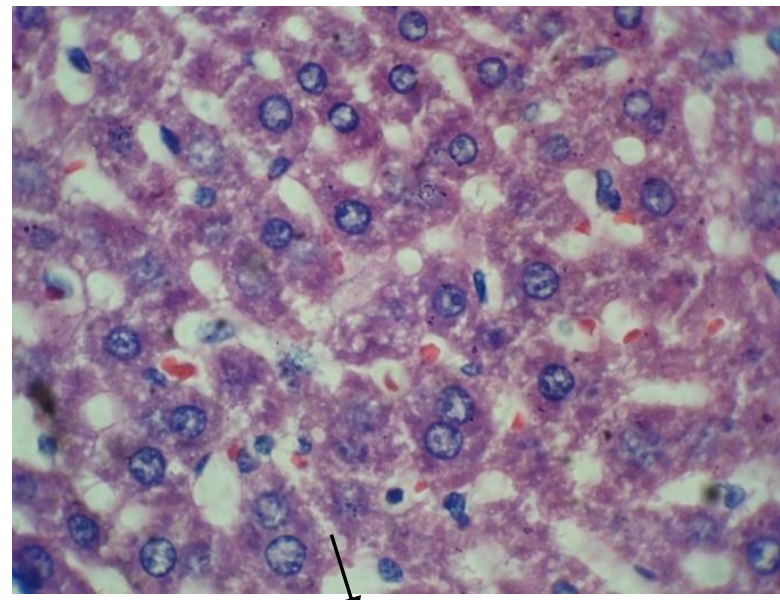

HE staining examination of control group (1000X magnification)

There were cells with enlarge nucleus (arrow, the mean percentage was $17.65 \%)$

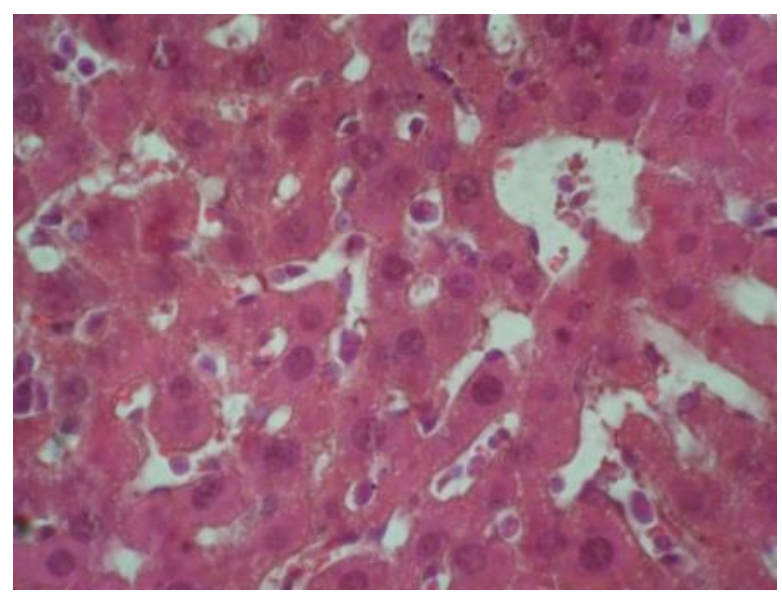

HE staining examination of group 1 (1000X magnification)

The mean percentage of abnormal cells was $40.93 \%$

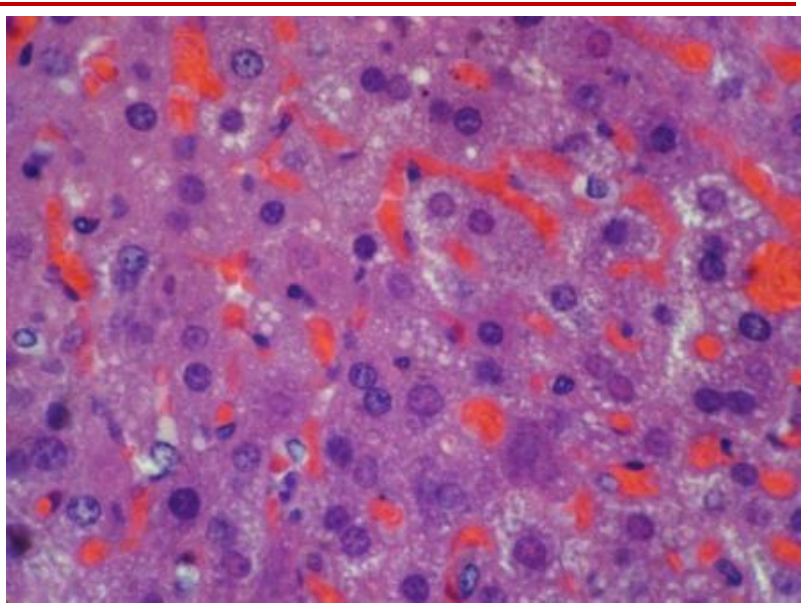

HE staining examination of group 2 (1000X magnification) The mean percentage of abnormal cells was $51.94 \%$

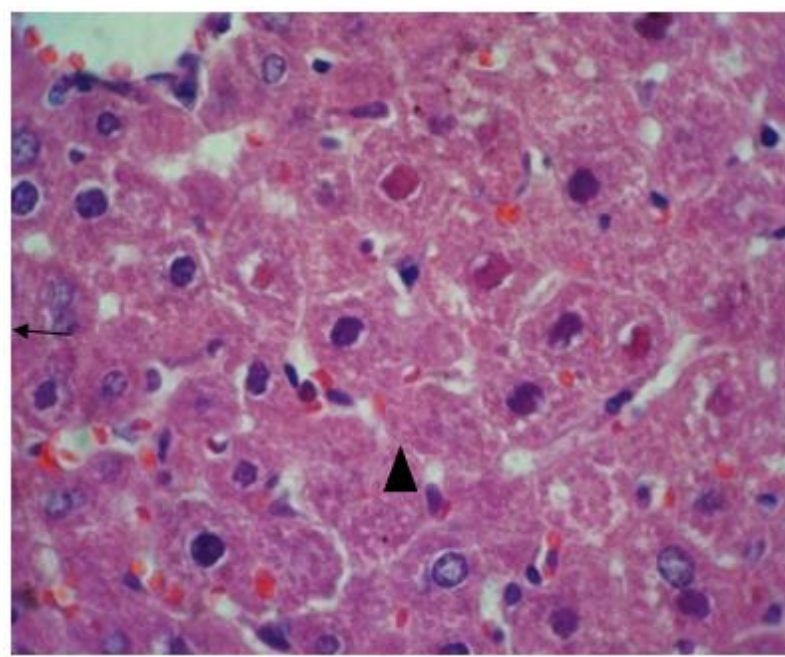

HE staining examination of group 3 (1000X magnification) The mean percentage of abnormal cells was $61.22 \%$. Karyorhexis (arrow), karyolysis (arrow head)

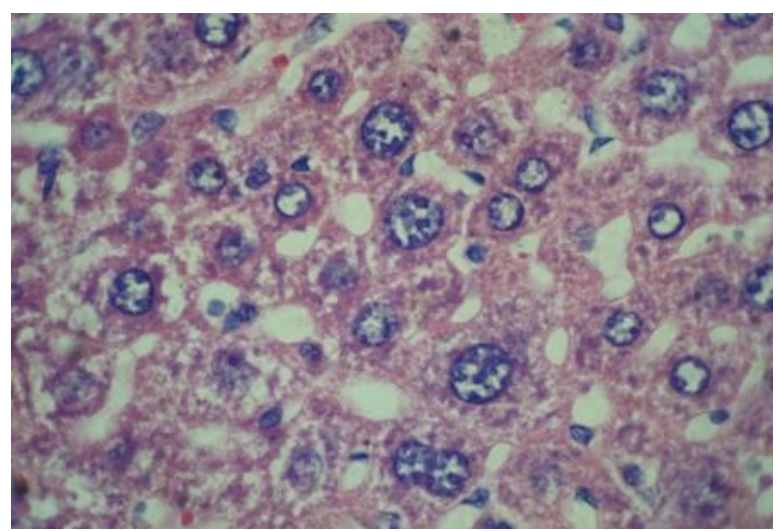

HE staining examination of group 4 (1000X magnification) The mean percentage of abnormal cells was $60.77 \%$ 
Aisha Abduljalil Ashammam et al., Saudi J Biomed Res, Jan, 2022; 7(1): 1-20

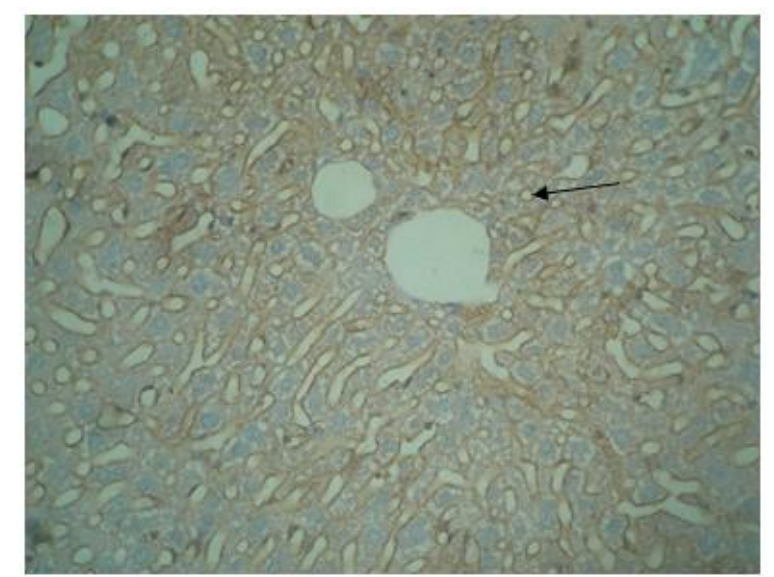

IHC staining examination of control group Morphology of P450 expression of the Balb c/ mice liver cells in control group, using 400X magnification. The cells were slightly brown coloured (arrow). The mean score of P450 expression was 185.83

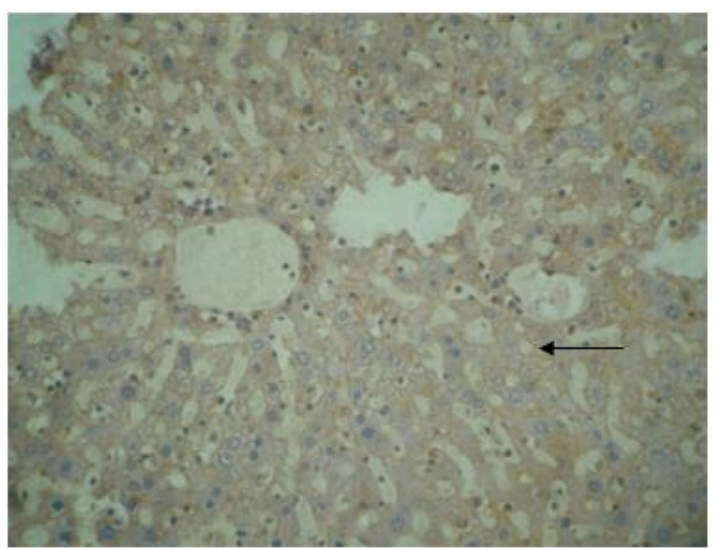

IHC staining examination of group 1

Morphology of P450 expression of the Balb c/ mice liver cells in group 1,using 400X magnification. The cells were mediumly brown coloured (arrow). The mean score of P450 expression was 251.67

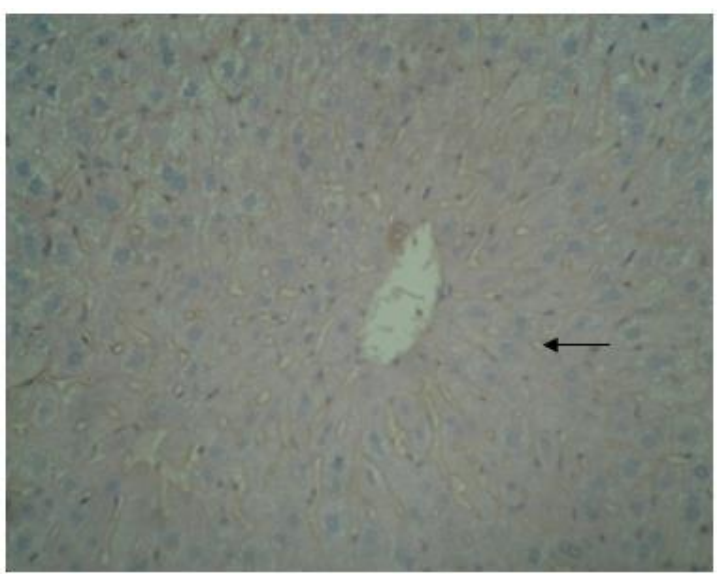

IHC staining examination of group 2

Morphology of P450 expression of the Balb c/ mice liver cells in group 2,using 400X magnification. The cells were slightly brown coloured (arrow).

The mean score of $\mathrm{P} 450$ expression was 183.33

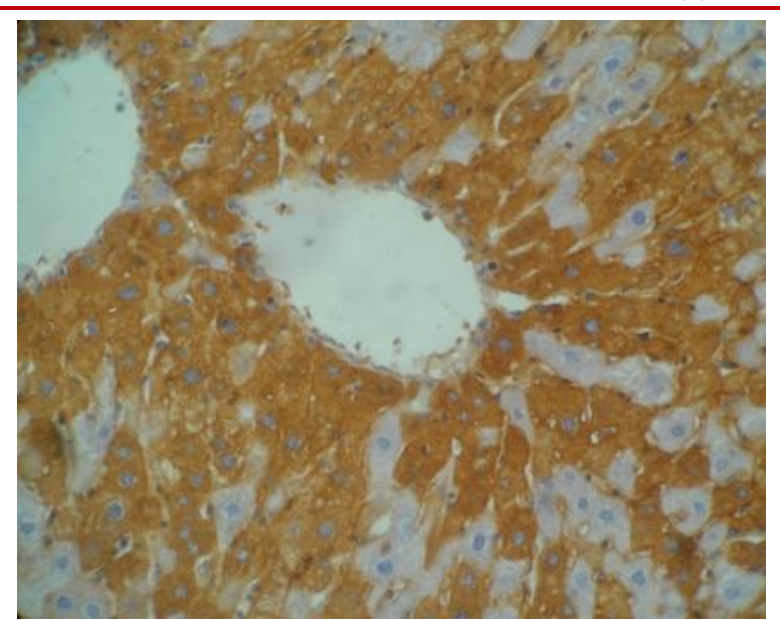

IHC staining examination of group 3

Morphology of P450 expression of the Balb c/ mice liver cells in group 3, using 400X magnification. The cells were intensely brown coloured (arrow). The mean score of P450 expression was 231.67

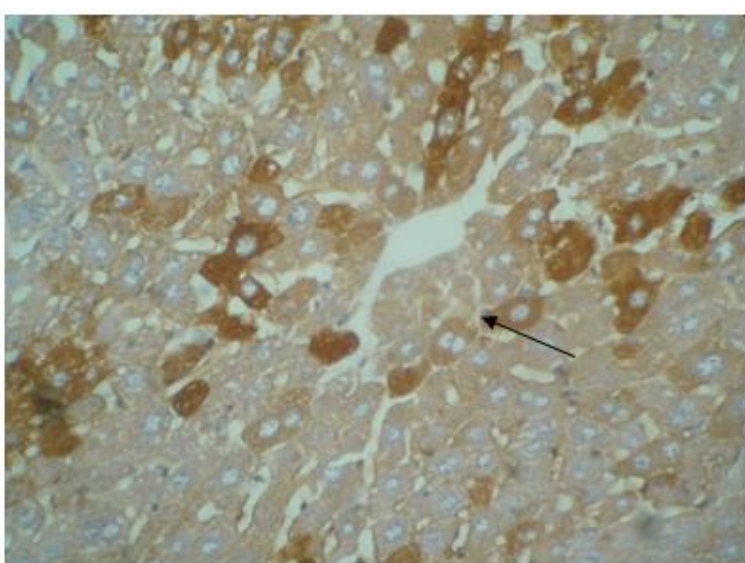

IHC staining examination of group 4

Morphology of P450 expression of the Balb c/ mice liver cells in group 4, using 400X magnification. The cells were intensely brown coloured (arrow).

The mean score of $\mathrm{P} 450$ expression was 216.67

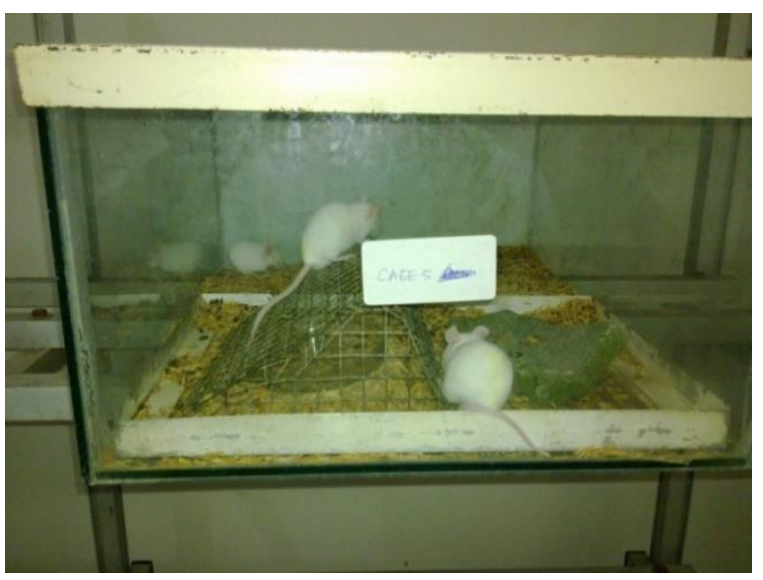

Male balb/C mice in the group 
Aisha Abduljalil Ashammam et al., Saudi J Biomed Res, Jan, 2022; 7(1): 1-20

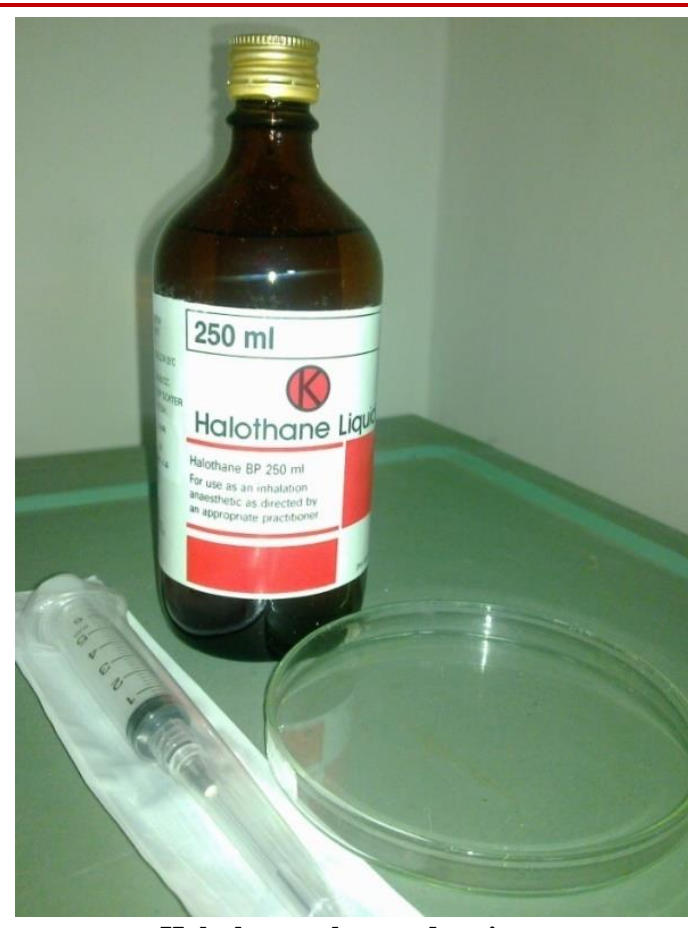

Halothane, plate and syringe

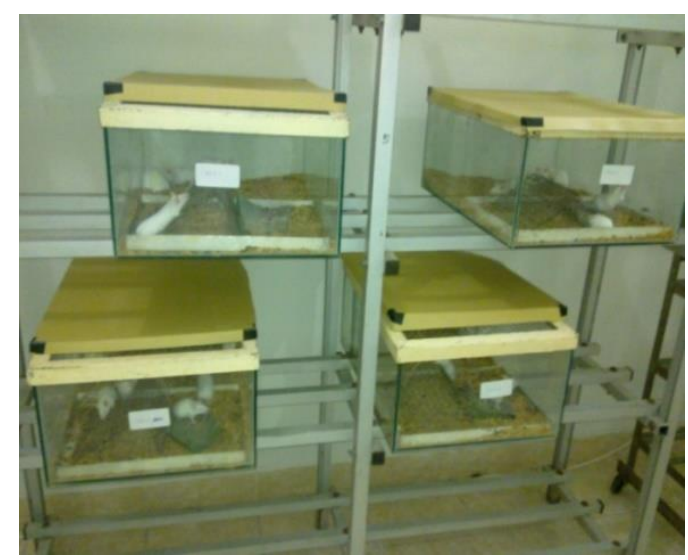

Mice on the cages

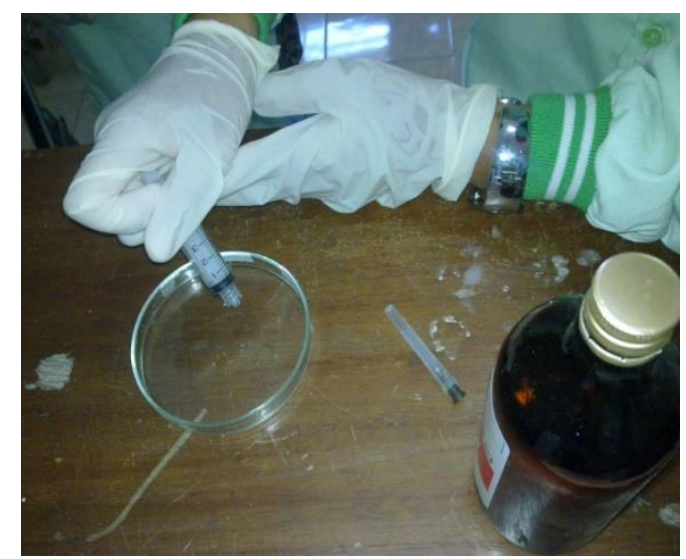

Halothane was put on a plate

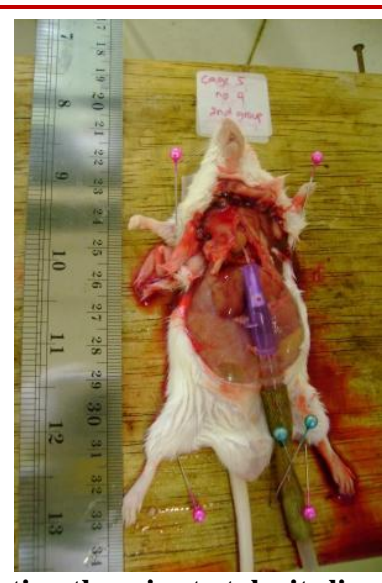

Operating the mice to take its liver tissue

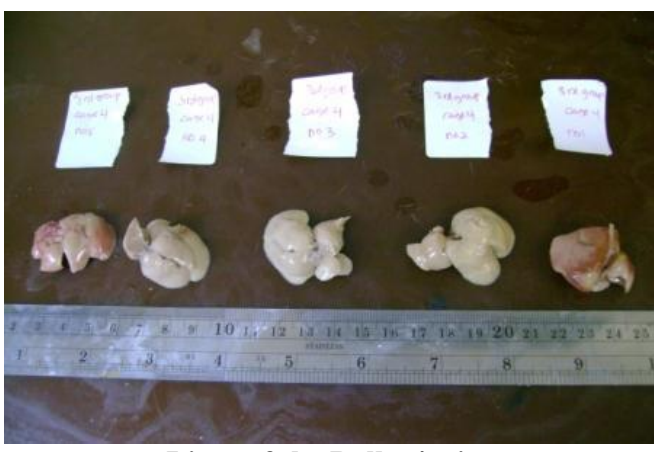

Liver of the Balb c/ mice

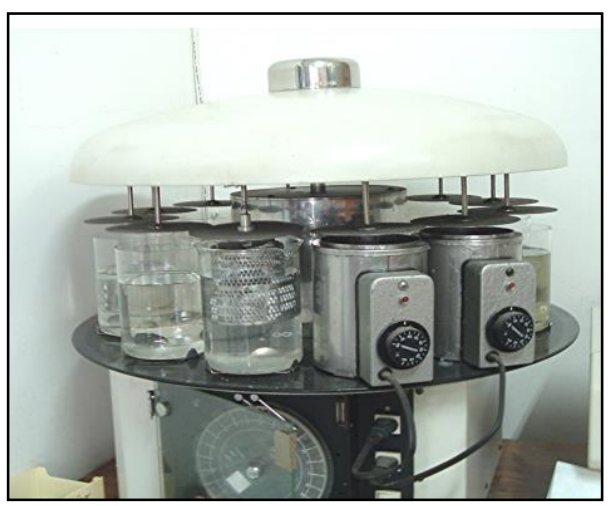

Histokinet

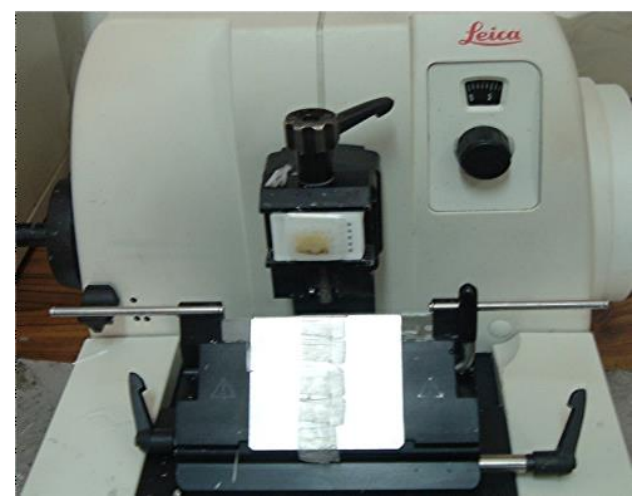

Microtome 